MARIAN SURDACKI* - LUBLIN

\title{
RODZAJE I FORMY JAŁMUŻNY W POLSCE PRZEDROZBIOROWEJ
}

\section{Jałmużna prywatna - indywidualna}

Pomoc udzielana ubogim przez szpitale oraz inne instytucje, organizacje, stowarzyszenia i fundacje dobroczynne zaspakajała zaledwie część potrzeb w zakresie opieki społecznej, można powiedzieć opieki instytucjonalnej. Dla ogromnych rzesz nędzarzy niezbędnym warunkiem przetrwania była dobroczynność indywidualna, realizowana z pobudek humanitarnych, religijnych, niekiedy praktycznych ${ }^{1}$. Jej najbardziej powszechną formę stanowiła jałmużna, tzw. „miłosierdzie na co dzień”, według średniowiecznej koncepcji miłosierdzia, „złoty” i uniwersalny środek zaradczy na wszelką nędzę ludzką, bowiem dostępny i możliwy do realizacji przez wszystkich ludzi z różnych stanów i grup społecznych. Pochwała ubóstwa zawarta w Piśmie Świętym i traktatach ojców Kościoła szła w parze z nakazem świadczenia jałmużny cierpiącym i biednym ${ }^{3}$. Dawanie jałmużny było czymś naturalnym i codziennym, wręcz wpisanym w mentalność społeczeństwa okresu najpierw średniowiecznego, później nowożytnego. Była ona ważnym elementem wszystkich uroczystości kościelnych i rodzinnych, zjazdów i spotkań publicznych oraz podróży ${ }^{4}$.

Działalność charytatywna, a przede wszystkim praktykowana w średniowieczu na ogromną skalę dobroczynność prywatna ${ }^{5}$, miała wymiar eschatologicz-

* Marian Surdacki - prof. historii, kierownik Katedry Historii Wychowania i Opieki Społecznej, Wydział Nauk Społecznych KUL, e-mail: msurd@kul.pl

${ }^{1}$ Z. Budzyński, Dzieje opieki społecznej w ziemi przemyskiej i sanockiej (XV-XVIII w.), Przemyśl-Kraków 1987, s. 161.

${ }^{2}$ A. Karpiński, Pauperes. O mieszkańcach Warszawy XVI i XVII wieku, Warszawa 1983, s. 346.

${ }^{3}$ B. Geremek, Święty Antoni z Florencji o żebrakach i jatmużnie, w: Wieki średnie. Medium aevum. Prace ofiarowane Tadeuszowi Manteuffelowi w 60 rocznicę urodzin, red. A. Gieysztor, M.H Serejski, S. Trawkowski, Warszawa 1962, s. 239.

${ }^{4}$ Budzyński, Dzieje opieki, s. 16; W. Partyka, Opieka społeczna w Ordynacji Zamojskiej w XVII-XVIII wieku, Lublin 2008, s. 243.

${ }^{5}$ K. Dola, Opieka spoteczna i zdrowotna w Gtogowie do czasów pruskich (1942), w: Misericordia et veritas. Księga pamiątkowa ku czci księdza biskupa Wincentego Urbana, red. J. Mandziuk, J. Pater, Wrocław 1986, s. 120. 
ny, w którym ubodzy zobowiązani byli odwzajemnić otrzymaną pomoc poprzez modlitwę za swego dobroczyńcę ${ }^{6}$. Jałmużna świadczona z czystego miłosierdzia i filantropii, ale także w trosce o życie wieczne, dawała możliwość odkupienia win, stanowiła dla niektórych wyraz kalkulacji i element średniowiecznej „ekonomii zbawienia” czy „filozofii zbawienia”. Skoro rozdawanie jałmużny w wiekach średnich, było obowiązkiem chrześcijanina, to żebrak był istotą społecznie niezbędną, gdyż stwarzał innym możliwość uzyskania życia wiecznego, wedle obrazowego określenia „biedni brać mogą innych do nieba"”. Z uwagi na spontaniczność, przypadkowość, często anonimowość jałmużny - zwłaszcza indywidualnej (prywatnej), jej zakres i skala jest trudno uchwytna i niepoliczalna, ponieważ jako gest często drobny i dyskretny na ogół nie była dokumentowana.

\section{Jałmużna testamentowa}

\section{a) na osoby indywidualne}

Nieco inaczej rzecz się miała z tzw. jałmużną testamentową, sformalizowaną i zarejestrowaną w dokumentach, tyle tylko że na taką pozwalali sobie zwykle ludzie bogatsi, którzy poprzez zapisy jałmużnicze, starali się utrwalić swoje miłosierne gesty i zobowiązać obdarowanych do długotrwałych modłów za swoją duszę po śmierci. Zapisy testamentowe jawią się jako najbardziej popularny sposób wspierania dzieł dobroczynnych, instytucji (szpitali) i stowarzyszeń (bractw), czy zakonów o regule opiekuńczej ${ }^{8}$. W testamentach, ofiary na cele charytatywne mają swoje naturalne miejsce, stanową narzędzie odkupienia grzechów, zadośćuczynienia za popełnione $\mathrm{w}$ życiu błędy ${ }^{9}$. W indywidualnych wypadkach dużą rolę odgrywała też chęć uwiecznienia samego siebie, związania swego nazwiska z zasługą i dobrym uczynkiem ${ }^{10}$, a także wiara, że jałmużna testamentowa zapewni życie wieczne ${ }^{11}$.

Oprócz testamentów obdarzających instytucje, istniały zapisy testamentowe wprost na konkretną osobę lub na grupę takich osób. Na przykład w testa-

${ }^{6}$ E. Wółkiewicz, Formy dobroczynności w miastach śląskich $w$ średniowieczu, „Kwartalnik Historii Kultury Materialnej”, 58 (2010) nr 2, s. 211; A. Rodziński, Bogactwo i ubóstwo w świetle myśli chrześcijańskiej pierwszych trzech stuleci, „Vox Patrum”, 16 (1996) z. 30-31, s. 87.

${ }^{7}$ Geremek, Święty Antoni, s. 239; tenże, Żebracy w Italii późnego średniowiecza: Obraz literacki a środowisko społeczne, w: Społeczeństwo. Gospodarka. Kultura. Studia ofiarowane Marianowi Małowistowi w czterdziestolecie pracy naukowej, Warszawa 1974, s. 96.

${ }^{8}$ Por. P. Oliński, Mieszczanin w trosce o zbawienie. Uwagi o memoratywnych funkcjach fundacji mieszczańskich $w$ wielkich miastach pruskich, w: Ecclesia e civitas. Kościót i życie religijne w mieście średniowiecznym, red. H. Manikowska, H. Zaremska, Warszawa 2002, s. 347-348, 351. Dobroczynna rola testamentów omawiana jest w niemalże wszystkich wcześniejszych rozdziałach.

${ }_{9}^{9}$ B. Geremek, Ludzie marginesu społecznego w średniowiecznym Paryżu XIV-XV wiek, Wrocław 1971, s. 181.

${ }^{10}$ A. Karpiński, Kobieta $w$ mieście polskim $w$ drugiej połowie XVI $i$ w XVII wieku, Warszawa 1996, s. 244; K. Justyniarska-Chojak, Legaty „pobożne” dla bractw religijnych w Nowym Saczu (w pierwszej połowie XVII wieku), w: Bractwa religijne $w$ średniowieczu $i$ w okresie nowożytnym (do końca XVIII wieku), red. D. Burdzy, B. Wojciechowska, Kielce 2014, s. 237.

${ }^{11}$ B. Możejko, Rozrachunek z życiem doczesnym. Gdańskie testamenty mieszczańskie z XV i początku XVI wieku, Gdańsk 2010, s. 49. 
mentach paryskich najwięcej miejsca zajmują polecenia rozdawnictwa jałmużny wśród żebraków, biednych szpitalnych, czy wśród więźniów. Testamenty często też obdarzały jałmużną ubogie rodziny, wdowy sieroty i panny na wydaniu, nie posiadające posagu. W średniowiecznym Paryżu istniały specjalnie wyznaczone miejsca (szpitale, kościoły), w których zwykli byli przebywać żebracy i w których rozdawano jałmużny testamentowe $e^{12}$.

Gloryfikacja, nobilitacja ubogiego w średniowieczu i traktowanie go, zgodnie z hasłem res sacra miser, jako pauperes Christi, któremu nie można odmawiać wsparcia powodowały, że również na ziemiach polskich dyspozycje dotyczące świadczenia jałmużny znajdowały ważne miejsce w aktach ostatniej woli. Ludzie wierzacy uważali ówcześnie, że biedni istnieja po to, aby okazywać im miłosierdzie, dzielić z nimi tym co się posiada ${ }^{13}$. W XIV i XV wieku zapisy testamentowe oraz darowizny na rzecz żebraków i ubogich były bardzo popularne na Śląsku. Wyróżniał się pod tym względem szczególnie Wrocław ${ }^{14}$. W końcu XV w. nie było niemal testamentu zamożniejszego mieszczanina, w którym nie występowałby zapis, czynszu czy gotówki dla ubogich ${ }^{15}$. W 1495 r. radny i ławnik wrocławski Kaspar Poplau nakazał spadkobiercom sporządzić listę 47 ubogich z Wrocławia, gromadzić ich w każdą suchedniową sobotę na katechizację i rozdawać im potem pieniądze i żywność. Niezliczoną liczbę zapisów z podobną klauzulą można było spotkać w wiekach XV i XVI w testamentach czynionych przez duchownych i mieszczan na terenie całej Polski, np. w Krakowie, Poznaniu, Gdańsku, Lwowie, Wrocławiu. Oprócz zamożnych mieszczan sumy na rzecz ubogich, rozdzielane zazwyczaj w rocznice śmierci, zapisywali też obywatele miast o niższym statusie materialnym ${ }^{16}$. Za pomocą legatów i zapisów testamentowych pro pauperes, swą religijność, miłosierdzie oraz troskę o ubogich i chorych manifestowali też mieszczanie późnośredniowiecznej Warszawy ${ }^{17}$.

Również w okresie staropolskim większość aktów ostatniej woli zawierała legaty na rzecz określonej grupy ubogich ${ }^{18}$. Niemal wszystkie testamenty zawierały klauzule, zobowiązujące rodzinę testatora do zapewnienia udziału ubogich w uroczystościach pogrzebowych oraz wynagrodzenia ich w formie żywności lub pieniędzy ${ }^{19}$. Autorkami zapisów testamentowych, wspomagających biednych,

${ }^{12}$ Geremek, Ludzie marginesu, s. 183-187.

${ }^{13}$ Z. Góralski, Opieka spoleczna i szpitalnictwo $w$ dawnej Polsce (na przykładzie Lubelszczyzny), „Zeszyty Historyczne Uniwersytetu Warszawskiego”, 3 (1963) s. 84-86.

${ }^{14}$ R. Heck, Struktura społeczna średniowiecznego Wrocławia na przełomie XIV/XV wieku, „Śląski Kwartalnik Historyczny Sobótka”, 7 (1952) s. 84.

${ }^{15}$ D Lapis, B. Lapis, Beginki w Polsce w XVIII-XV wieku, „Kwartalnik Historyczny”, 79 (1972) nr 3, s. 528.

${ }^{16}$ K. Dola, Opieka społeczna Kościoła, w: Historia Kościoła w Polsce, t. 1, cz. 1, red. B. Kumor, Z. Obertyński, Poznań-Warszawa 1974, s. 434; D. Lapis, B. Lapis, Beginki w Polsce, s. 528.

${ }^{17} \mathrm{~K}$. Mrozowski, Religijność mieszczan późnośredniowiecznej Warszawy w świetle najstarszych zachowanych testamentów, „Kwartalnik Historii Kultury Materialnej”, 58 (2010) nr 2, s. 195.

${ }^{18}$ Budzyński, Dzieje opieki s. 162.

${ }^{19}$ A. Przyboś, Rzeszów na przełomie XVI i XVII wieku, w: Pięć wieków miasta Rzeszowa, Warszawa 1958, red. F. Błoński, s. 115; Budzyński, Dzieje opieki, s. 142. 
samotne wdowy czy szpitale, były niejednokrotnie kobiety, zarówno bogate, jak i biedne ${ }^{20}$, także ewangeliczki. Między innymi testamentem z 1667 r. kalwinka Anna Maria Radziwiłłowa ofiarowała 1000 zł. na potrzeby ubogich. Taką samą sumę dla wdów, ubogich i sierot ze zborów kalwińskich zapisała w $1674 \mathrm{r}$. w akcie przedśmiertnym wojewodzina wileńska Katarzyna z Radziwiłłów Hlebowiczowa. Ponadto darowała pewne sumy dla swych ubogich sług i czeladzi ${ }^{21}$. Darowizn ewangeliczek na dobroczynność, szpitale czy szkoły, ze względu na odmienności teologiczne, nie można traktować jako zasługi, tak jak u katoliczek. Chodziło raczej o zadbanie o los współwyznawców i utrzymanie wzorcowej dla nich postawy ${ }^{22}$. Obdarowywanie datkami służby i czeladzi przez testatorki było w XVI i XVII w. zjawiskiem nagminnym w większych miastach polskich ${ }^{23}$. Występowało ono wśród szlachty krakowskiej, która czyniła w testamentach legaty pieniężne dla ubogich mieszkających w szpitalach ${ }^{24}$. Wdzięczność i uznanie wiernym sługom wyrażali też na łożu śmierci poprzez testamenty mieszkańcy miasteczek wielkopolskich ${ }^{25}$.

Wśród testamentów kobiecych pięciu dużych miast (Poznań, Lublin, Lwów, Warszawa, Kraków), spisywanych w XVI i XVII wieku 58\% zawiera informacje o legatach na cele religijne i dobroczynne ${ }^{26}$. Jeszcze większa ofiarność cechowała kobiety z uboższych warstw (służące domowe), które w aż 87\% testamentów dokonywały legatów na wymienione cele. W porównaniu z kobietami, znacznie mniej skłonni do dobroczynnych legatów testamentowych byli mężczyźni ${ }^{27}$.

Dobroczynność prywatną doskonale egzemplifikują testamenty lwowskie, w których spotykamy liczne legaty na obiady i łaźnie dla ubogich, na sukno dla mendykantów, tj. jest dla biednych żaczków szkolnych, na zubożałych rzemieślników ${ }^{28}$. Lwowianie nie pomijali w aktach ostatniej woli osób najbardziej zdegradowanych, tj. żebraków miejskich. Przykładowo jeden z nich w 1635 r. przekazał

${ }^{20}$ L. Sieciechowiczowa, Życie codzienne $w$ renesansowym Poznaniu 1518-1619, Warszawa 1976, s. $62-63$.

${ }^{21}$ U. Augustyniak, Testamenty ewangelików reformowanych $w$ Wielkim Księstwie Litewskim, Warszawa 1992, s. 191, 217, 220.

${ }^{22}$ E. Lesiak, Kobiety z rodu Radziwitlów w świetle inwentarzy i testamentów (XVI-XVIII w.), w: Administracja i życie codzienne w dobrach Radziwiltów XVI-XVIII wieku, red. U. Augustyniak, Warszawa 2009, s. 173; U. Augustyniak, Wizerunek Krzysztofa II Radziwiłla jako magnata-ewangelika w świetle jego testamentów, „Przegląd Historyczny”, 81 (1990) z. 3-4, s. 466-467.

${ }^{23}$ Karpiński, Kobieta, s. 282-283.

${ }^{24} \mathrm{~Np}$. testament Stanisława Łętowskiego z 1773 r. z zapisem dla swych sług i ubogich szpitala w Modlnicy. Testamenty szlachty krakowskiej XVII-XVIII w. opr. A. Faleniowska-Gradowska, Kraków 1997, s. 148-149.

${ }^{25}$ A. Głowacka-Penczyńska, Testamenty mieszkańców małych miast wielkopolskich z XVII wie$k u$, „Kwartalnik Historii Kultury Materialnej”, 59 (2011) nr 3-4, s. 391.

${ }^{26}$ Karpiński, Kobieta, s. 252.

${ }^{27}$ Tamże, s. 253.

${ }^{28}$ W. Łoziński, Patrycjat i mieszczaństwo lwowskie w XVI i XVII wieku, Lwów 1902, s. 25; Karpiński, Opieka spoteczna, s. 25. 
testamentem 170 złotych „na ubogich po drogach i gnojach leżących albo na ubogich mieszczan" 29

Pojęcie „ubogi” w owych czasach nie posiadało jednoznacznych konotacji. W najbardziej wąskim i powszechnym znaczeniu określano nim nędzarzy i żebraków ulicznych, w szerszym rozumieniu obejmowało szeroki „konglomerat” osób znajdujących się w potrzebie. Niektórzy testatorzy, czyniąc zapisy na ubogich mieli na względzie jedynie tych pierwszych ${ }^{30}$, inni zaś różne kategorie ubogiej ludności. Przykładem tej drugiej dyspozycji przedśmiertnej jest testament z 1521 roku mieszczanki gdańskiej Elżbiety, wdowy po Dicku de Bastes, w którym „po 100 grzywien przeznaczyła dla każdego z następujących odbiorców: dla domu pokutnic; na szare sukno dla ubogich; dla bezdomnych; dla ubogich dziewcząt, 10 grzywien na buty dla ubogich ludzi i uczniów". Oprócz tego dokonała innych legatów na cele charytatywne, tj. na trzy szpitale lwowskie oraz po 10 grzywien na kąpiel ubogich przebywających w tych placówkach ${ }^{31}$.

Kategorie osób obdarzanych jałmużną testamentową były niezwykle szerokie. Obejmowały nie tylko żebraków i nędzarzy, ale też ludzi młodych, uczniów i scholarów, chłopców podejmujących naukę rzemiosł, dziewczęta zamierzające wyjść za mąż (posagi), prostytutki, kobiety spodziewające się dziecka, rodziny wielodzietne, czy wdowy. Odrębny rodzaj zapisów charytatywnych stanowiły nadania na rzecz schorowanych oraz ubogich duchownych. Na uwagę zasługują renty zapisywane $\mathrm{w}$ testamentach dla osób, które zamierzały wstąpić do stanu duchowego czy dla kościelnych organistów ${ }^{32}$.

Legaty w testamentach na rzecz ubogich, choć często inspirowane motywami ewangelicznymi, dla ogółu wiernych, tak świeckich, jak i duchownych, stanowiły gest dobrowolny. W wypadku księży każdy z nich miał prawo, a nawet obowiązek sporządzenia testamentu. Gdy jednak zmarły kapłan nie dokonał tej czynności, siedemnastowieczne statuty kapituły wileńskiej nakazywały, by po spłaceniu pozostawionych zobowiązań, nadwyżki lub pozostałość jego majętności przeznaczyć dla ubogich ${ }^{33}$.

Nierzadko zdarzały się przypadki wymuszania przez ubogich korzystnych donacji charytatywnych od legatariuszy stających u kresu doczesnego życia. Takie praktyki stosowały w XIV w. siostry beginki, które sprawdzały do których domów był niesiony wiatyk, żeby u osób leżących na łożu śmierci wypraszać darowizny ${ }^{34}$.

Zapisy testamentowe na jałmużnę dla biednych, z czasem wzbogacane i łączone $\mathrm{z}$ kolejnymi podobnymi legatami, przekształcały się niekiedy $\mathrm{w}$ trwałe fun-

${ }^{29}$ A. Karpiński, Dobroczynne i religijne legaty lwowskich mieszczan w świetle ich testamentów z lat 1550- 1700, „Kwartalnik Historii Kultury Materialnej”, 59 (2011) nr 3-4, s. 367, 372, 377.

${ }^{30}$ Możejko, Rozrachunek, s. 50, 56, 58, 63, 70, 72-73, 77.

${ }^{31}$ Tamże, s. 81. Zob. też krytyczne opracowane cytowanej książki: W. Długokęcki, $W$ sprawie późnośredniowiecznych testamentów gdańskich, „Zapiski Historyczne”, 76 (2011) z. 3, s. 132 i inne.

${ }^{32}$ Wółkiewicz, Formy dobroczynności, s. 221-223, 225

${ }^{33} \mathrm{~W}$. Pawlikowska, Testamenty duchowieństwa diecezji wileńskiej $w$ drugiej połowie XVI $w$. Prawo i praktyka, „Kwartalnik Historii Kultury Materialnej”, 59 (2011) nr 3-4, s. 396-397.

${ }^{34}$ Wółkiewicz, Formy dobroczynności, s. 225. 
dusze, a nawet fundacje charytatywne, z których korzystali potrzebujący przez kilka stuleci. Taki proces przeszła donacja testamentowa przeznaczona w $1455 \mathrm{r}$. przez małżeństwo Beyersdorfów z Głogowa na wspomaganie biednych. Funkcjonowała ona jeszcze w 1781 r. przy kościele św. Mikołaja, jednak już jako bardzo bogata zbiorowa fundacja, złożona $\mathrm{z}$ wielu indywidualnych zapisów ${ }^{35}$.

Wsparcie ubogich jałmużną testamentową przyjmowało najczęściej formę drobnych kwot lub nadań w naturze. Rozdawnictwo gotówki odbywało się zazwyczaj jako wynagrodzenie za udział w liturgii pogrzebowej bądź w mszach anniwerersaryjnych fundatora. Rzadziej zdarzały się przypadki związane z jednorazową wypłatą dokonywaną po śmierci ofiarodawcy ${ }^{36}$. Ci ostatni zapisując gotówkę dla biednych z reguły nie określali celu, na który ma być wykorzystana, niekiedy jednak konkretnie precyzowali jej przeznaczenie, np. na jedzenie, łaźnię czy kąpiel ${ }^{37}$.

Oprócz pieniędzy przedmiotem najczęstszej troski fundatorów było zaopatrzenie ubogich w ubrania i buty. Równie często zamiast gotowych ubrań obdarzano ubogich suknem, które później wykorzystywali na szycie konkretnej odzie$\dot{z} y^{38}$. Często przedmiotem fundacji testamentowych było pożywienie, szczególnie chleb, rzadziej bułki, darowano też produkty naturalne w postaci ziarna zboża, a sporadycznie mięso i śledzie. $Z$ uwagi na styl życia i wynikający z niego deficyt higieny, ciepła i zdrowia, bardzo ważnym darem dla ubogich były fundacje darmowych kąpieli, opału, niekiedy, usług fryzjerskich i pralniczych lub dużo rzadziej opłacenie lekarstw czy medyka. Incydentalnie spotykane były legaty księgozbiorów na rzecz niezamożnych uczniów i ubogich księży ${ }^{39}$.

Zupełnie inną kwestię są zapisy testamentowe na szpitale i mieszkających w nich pensjonariuszy. Katalog ofiarowywanych rzeczy był jeszcze dużo bogatszy, niż w wypadku ubogich poza szpitalnych. Powszechnym zwyczajem było np. zapisywanie instytucjom charytatywnym żywności bądź zwierząt, które znajdowały się w gospodarstwie w momencie śmierci dobroczyńcy ${ }^{40}$.

\section{b) na instytucje dobroczynne}

W jeszcze większej skali niż na tzw. dobroczynność indywidualną i nie instytucjonalną testatorzy dokonywali zapisów na wspieranie i finansowanie placówek opiekuńczych. Legaty i darowizny w testamentach na szpitale często czynili w XIV w. mieszczanie krakowscy ${ }^{41}$. Zapisy testamentowe miały decydujący wpływ na finanse i funkcjonowanie np. elbląskiego szpitala św. Jerzego (Bożego

${ }^{35}$ Dola, Opieka społeczna i zdrowotna, s. 120-121.

${ }^{36}$ Wółkiewicz, Formy dobroczynności, s. 216.

${ }^{37}$ Możejko, Rozrachunek, s. 58, 72-73, 81.

${ }^{38}$ Wółkiewicz, Formy dobroczynności, s. 217-218; Możejko, Rozrachunek, s. 56, 63, 70, 77.

${ }^{39}$ Wółkiewicz, Formy dobroczynności, s. 217, 219-221.

${ }^{40}$ Tamże, s. 215.

${ }^{41} \mathrm{~J}$. Wysmułek, Przejawy religijności mieszczan krakowskich na podstawie XIV-wiecznych testamentów i zapisów pobożnych, „Odrodzenie i Reformacja w Polsce”, 54 (2010) s. 102-103. 
Ciała) w pierwszej połowie XV wieku ${ }^{42}$. W XV i na początku XVI w. większość dochodów na swą działalność $\mathrm{z}$ bardzo licznych legatów testamentowych czerpały niemal wszystkie szpitale gdańskie. Ponadto dochodziły do tego zapisy na samych pensjonariuszy szpitalnych ${ }^{43}$.

Dyspozycje testamentowe przeznaczane na instytucje i organizacje charytatywne nasiliły się szczególnie w XVI w., kiedy nastąpiła rewizja mediewistycznej doktryny o miłosierdziu i jałmużnie, a tym samym zmiana postaw społecznych w stosunku do pauperes $^{44}$. Nowożytna reforma filantropii, dokonana pod wpływem ideologii protestanckiej zdeterminowała w dużym stopniu styl i formę siedemnastowiecznej dobroczynności. W miejsce każdego anonimowego żebraka, któremu w średniowieczu należało się miłosierne wsparcie, pomagano tylko faktycznie potrzebującym, godnym jałmużny lub innej pomocy. Obiektem zainteresowań legatariuszy coraz częściej byli pensjonariusze szpitali i przytułków ${ }^{45}$. Przykładowo na przestrzeni XVII i XVIII wieku tylko na utrzymanie szpitala św. Leonarda $\mathrm{w}$ Łowiczu dokonano przynajmniej 35 fundacji pieniężnych, w większości testamentowych. W każdym niemal testamencie duchownego, mieszczanina, szlachcica czy nawet chłopa były jakieś sumy zapisane dla biednych w łowickich szpitalach w zamian za ich modlitwy i udział w pogrzebie ${ }^{46}$. Testament Jakuba Szolca mieszczanina lwowskiego, zmarłego w 1743 r., oprócz legatów na wszystkie miejscowe zakony i szpitale, uwzględniał zapisy na ubogie dziewice i matrony, na łaźnie dla biednych, a także osobny kapitał „dla sierotek miejskich i sługi" ${ }^{47}$. W okresie od drugiej połowy XVI do końca XVII w. wśród instytucji Poznania, Lublina, Krakowa i Lwowa, obdarowywanych testamentami przez kobiety, $22 \%$ datków szło na szpitale ${ }^{48}$. W XVII w. spośród testamentów mieszkańców miasteczek wielkopolskich, uwzględniających dotacje na cele kościelno-dobroczynne, w $28 \%$ z nich znajdowały się zapisy na szpitale, a w $11 \%$,na miłosierne uczynki i dla ubogich" ${ }^{\text {" }}$. W sporządzaniu zapisów testamentowych na rzecz szpitali uczestniczyli przedstawiciele wszystkich stanów społecznych, także duchowni. Między innymi kapłani z diecezji płockiej dokonali w XVII w. 8 legatów na 6 placówek szpitalnych ${ }^{50}$.

${ }^{42}$ R. Czaja, Rozwój szpitali miejskich w państwie Zakonu Krzyżackiego w Prusach, w: Szpitalnictwo $w$ dawnej Polsce, red. M. Dąbrowska, J. Kruppé, Warszawa 1998, s. 141.

${ }^{43}$ Możejko, Rozrachunek, s. 52, 56-59, 62, 64, 66, 69, 72, 74-77, 79-81, tabela II.

${ }^{44}$ M. Surdacki, Opieka społeczna w Wielkopolsce Zachodniej w XVII i XVIII wieku, Lublin 1992, s. 10-105.

${ }^{45}$ Karpiński, Kobieta, s. 278; Lesiak, Kobiety, s. 174; A. Szarszewski, Dokumenty fundacji nieszpitalnych jako źródło do badań na d struktura wewnętrzna szpitali gdańskich w XVII i XVIII wieku, „Rocznik Gdański”, 56 (2006) s. 164.

${ }^{46}$ P. Staniszewski, Szpitalnictwo kościelne $w$ archidiakonacie tęczyckim i towickim do 1795 roku, Warszawa 2004, s. 144.

${ }^{47}$ Loziński, Patrycjat i mieszczaństwo, s. 25.

${ }^{48}$ Karpiński, Kobieta, s. 255.

${ }^{49}$ Głowacka-Penczyńska, Testamenty mieszkańców, s. 389.

${ }^{50}$ D. Główka, Legaty pieniężne i rzeczowe na rzecz instytucji kościelnych w testamentach duchownych z diecezji płockiej w XVII wieku, „Kwartalnik Historii Kultury Materialnej”, 59 (2011) nr 
Po pewnej koniunkturze, jaką przeżywały legaty testamentowe na przytułki, w następnym stuleciu nastąpił wyraźny spadek liczby zapisów na szpitale w aktach ostatniej woli. Dowodzi tego sytuacja we Lwowie, gdzie w stosunku do trzeciej ćwierci XVI w., liczba donacji testamentowych na szpitale w około 75 lat później zmniejszyła się około dwu-trzykrotnie ${ }^{51}$. Zarówno w okresie późnego średniowiecza, jak i w czasach nowożytnych, sporządzający testamenty, nad dzieła miłosierdzia przedkładali tradycyjne świadczenia liturgiczne i wsparcie kościoła, adresując swe zapisy przede wszystkim do instytucji religijnych: klasztorów, kościołów, czy konkretnych kaplic i ołtarzy oraz bractw ${ }^{52}$.

Legaty testamentowe na szpitale przyjmowały różną formę. Oprócz kapitałów pieniężnych, równie często zdarzały się zapisy bezgotówkowe, w naturze, nieruchomościach, gruntach, budynkach, przedmiotach codziennego użytku, itp. ${ }^{53}$ Przykładowo w 1598 roku jeden z duchownych wileńskich przeznaczył wszelkie naczynia, sztućce, ubrania i inne mobilia ad opera pia ${ }^{54}$. Fundowanie szpitali lub ich uposażanie w wyniku realizacji zapisów testamentowych stanowi odrębny problem. Można tu tylko stwierdzić, że decyzjom i legatom zapisanym w aktach ostatniej woli zawdzięcza swoje powstanie i dalszą działalność ogromna liczba, a być może większość polskich instytucji charytatywnych. Z rzadszych wymienić tu można mons pietatis, zasilany dotacjami zapisywanymi w rozporządzeniach ostatniej woli przez mieszczan lwowskich ${ }^{55}$. Z darowizn testamentowych korzystały też bractwa dobroczynne, np. w 1518 r. gdańskie bractwo ubogich ${ }^{56}$, które później samo szafowało między ubogich otrzymana jałmużnę

\section{Jałmużna nietestamentowa}

Najczęściej spotykaną, najbardziej dyskrecjonalną, najsłabiej rejestrowaną w źródłach i z reguły materialnie najskromniejszą (tzw. „wdowi grosz”) była jałmużna indywidualna, świadczona przez prywatne osoby dla różnych kategorii potrzebujących mieszkających we własnych domach, w szpitalach bądź żyjących na ulicach bezdomnych żebraków. Pomimo przeobrażeń, jakie zaszły w okresie potrydenckim $w$ stosunku społeczeństwa do ubogich i ogólnej deprecjacji jałmużny, ta ostatnia nadal stanowiła niezastąpiony środek w sytuacjach, gdy zawodziły wszelkie inne sposoby wspomagania. Dlatego synody polskie często apelowały o wspomaganie indywidualne potrzebujących. Po raz pierwszy na ten temat wypowiedział się w Epistola Pastoralis w 1601 r. bp Bernard Maciejowski, który zachęcał wiernych do składania codziennych jałmużn „szpitalnikom”" ${ }^{\text {. Zalecenie }}$

3-4, s. 412. Zapisy testamentowe na szpital czynili też mieszczanie urzędowscy. Zob. M. Surdacki, Edukacja i opieka społeczna w Urzędowie XV-XVIII wieku, Lublin 2014, s. 284.

${ }^{51}$ Karpiński, Dobroczynne, s. 367, 377.

${ }^{52}$ Wółkiewicz, Formy dobroczynności, s. 214-215; Karpiński, Dobroczynne, s. 377.

${ }^{53}$ Karpiński, Kobieta, s. 277; Z. Góralski, Szpitale na Lubelszczyźnie w okresie przedrozbiorowym w okresie przedrozbiorowym, Warszawa-Łódź 1982, s. 96-97; Budzyński, Dzieje opieki, s. 49.

${ }^{54}$ Pawlikowska, Testamenty duchowieństwa, s. 400.

${ }^{55}$ Karpiński, Dobroczynne, s. 367, 377.

${ }^{56}$ Możejko, Rozrachunek, s. 82.

${ }^{57}$ Surdacki, Opieka spoleczna, s. 179; Maciejowski, Epistola pastoralis [...] 1601. 
takie zostało powtórzone w dekretach synodu warmińskiego z $1610 \mathrm{r}^{58}$ Apel do duchowieństwa, by zachęcali wiernych do udzielania hojnych jałmużn żebrakom swojej parafii wystosowano na synodzie płockim $\mathrm{w} 1733 \mathrm{r} .{ }^{59} \mathrm{Z}$ podobnym apelem zwrócił się do kleru swojej diecezji w 1739 r. biskup poznański Teodor Czartoryski $^{60}$. Wobec wielkich rzesz żebraków, na synodach (krakowski 1711, chełmiński 1745, lwowski 1765) zwracano się do plebanów, aby wszyscy chorzy i biedni, którym istniejące szpitale nie są w stanie zapewnić pomocy, byli wspierani jałmużną i otaczani pomocą tak wiernych, jak i duchownych w swoich parafiach ${ }^{61}$. Apele synodalne, dotyczące wzorów zachowań dobroczynnych były upowszechniane przez duchowieństwo świeckie i zakonne podczas kazań, rekolekcji i misji ludowych, często przez przykład własny ${ }^{62}$. We wszystkich tych odezwach, jałmużna pozainstytucjonalna, jawi się jako środek chwilowy, zastępczy, uzupełniający i łagodzący tam, gdzie nie istniały specjalnie powołane do tego placówki opiekuńcze - szpitale lub, gdy ich liczba i wielkość była niewystarczająca, a generalnie opieka instytucjonalna niewydolna ${ }^{63}$.

W swych apelach o hojność w świadczeniu jałmużny władze kościelne w okresie potrydenckim zachowywały jednak dużą ostrożność i krytycyzm w stosunku do żebraków i ogólnie pauperes, dbając, by pomoc dostawała się wyłącznie w ręce prawdziwych biedaków, a nie fałszywych, zdrowych i mogących pracować. Preferowały przy tym w obdarzaniu jałmużną swoich ubogich, $\mathrm{z}$ własnego środowiska, miasta, czy parafii ${ }^{64}$.

\section{a) dla pensjonariuszy szpitali}

Różnorodność sposobów wspierania ubogich utrudnia sporządzenie ich przejrzystej klasyfikacji i typologii ${ }^{65}$. Dotyczy to również jałmużny, form jej świadczenia przez darczyńców zdobywania oraz wyjednywania przez odbiorów, którzy przebywali w szpitalach lub pozostawali poza instytucjami opiekuńczymi. Procedurę, zasady i miejsce (rewiry) zbierania jałmużny przez pensjonariuszy szpitalnych ściśle określały i normowały władze i ustawodawstwo kościelne ${ }^{66}$. Ubodzy szpitalni byli nawet zobligowani do zbierania jałmużn, których gromadzenie zostało wpisane $\mathrm{w}$ ich obowiązki, gdyż wzmacniało podstawy materialne utrzymania, a niejednokrotnie było jedynym środkiem i sposobem wyżywienia oraz apro-

\footnotetext{
${ }^{58}$ Surdacki, Opieka spoteczna, s. 179; Constitutiones synodales dioecesis Varmiensis [...] 1610.

${ }^{59}$ Surdacki, Opieka społeczna, s. 108; Constitutiones et decrets synodi dioecesanae Plocensis

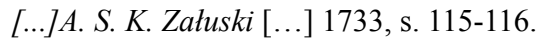

${ }^{60}$ Surdacki, Opieka społeczna, s. 108; Epistola pastoralis [...] T. Czartotyski [...] 1739.

${ }^{61}$ Surdacki, Opieka spoteczna, s. 108; Synodus dioecesana [...] K. Eubieński [...] 1711; Constitutiones synodales [...] A. S. K. Zatuski [...] 1745; Synodus dioecesana Leopoliensis [...] H. Sierakowski 1765.

${ }^{62}$ Budzyński, Dzieje opieki, s. 162.

${ }^{63}$ Por. Surdacki, Opieka społeczna, s. 109.

${ }^{64}$ Tamże, s. 114-117.

${ }^{65}$ Wółkiewicz, Formy dobroczynności, s. 215.

${ }^{66}$ Surdacki, Opieka spoleczna, s. 327.
} 
wizacji mieszkańców szpitali ${ }^{67}$. Można wyróżnić żebranie aktywne, polegające na chodzeniu od domu do domu po prośbie za chlebem i inną żywnością, niekiedy datkami pieniężnymi. W celu zapobieżenia chaosowi i naruszaniu porządku publicznego rządcy szpitali wybierali jednego z pensjonariuszy, najczęściej mężczyznę, który zaopatrzony w tabliczkę i zaświadczenie, w określone dni tygodnia, siedząc w obrębie miasta lub chodząc po domach oraz rynku i bezdrożach zbierał do kosza chleb i inne produkty żywnościowe dla ubogich. Zgromadzone pieniądze przeznaczano w części na szpital, w części na ubogich ${ }^{68}$.

Równie częstym, choć bardziej biernym, sposobem przekazywania jałmużny, zalecanym w 1601 r. w Pastoralnej przez bpa B. Maciejowskiego i synod warmiński z 1610 r., było dawanie jej siedzącym koło bramy kościoła żebrakom lub też wrzucanie pieniędzy do zamkniętych skrzynek (puszek), trzymanych przez upoważnionych do tego zbieraczy ${ }^{69}$ lub umieszczanych w kościołach ${ }^{70}$. Swoje skarbony umieszczane $\mathrm{w}$ kościele lub w miejscach publicznych miał prawie każdy szpital na Lubelszczyźnie. Szpital Św. Ducha w Lublinie wystawiał swoja skarbonę od 1781 r. w Trybunale na stole sędziowskim ${ }^{71}$. Kolejne synody pozwalając żebrzącym siedzenie u bram i podwoi kościołów lub w ich przedsionkach, zabraniały zarazem zakłócania mszy św., kręcenia się po świątyni w czasie jej trwania, a także natrętnego domagania się jałmużny ${ }^{72}$. Unikatowe zarządzenie wydano na synodzie diecezjalnym krakowskim z $1711 \mathrm{r}$. Aby nie stwarzać w kościołach, szczególnie miasta Krakowa, okazji do kłótni i wrzaw wynikających $\mathrm{z}$ jednoczesnego spotykania się ubogich z różnych miejsc, nakazano, by do każdego kościoła przypisać określoną ich liczbę ${ }^{73}$.

Wobec braku stałych funduszy i dotacji podstawą utrzymania pensjonariuszy w wielu szpitalach, oprócz przypadkowych i niepewnych jałmużn zdobytych w drodze żebrania pod kościołami, na drogach i po domach, były jałmużny, składane okazjonalnie lub stale na rzecz ,szpitalników” przez różne warstwy społeczeństwa bezpośrednio do szpitala. W 1610 r. pleban z parafii Brzezie zaopatrywał biednych szpitala w Starym Gostyniu w jarzyny i chleb, jak też wyznaczał każdemu z nich co jakiś czas 10 florenów i 6 groszy. Podobną pomoc w formie drobnych datków pieniężnych oraz warzyw otrzymywali od plebanów w XVII i XVIII wieku biedni z innych przytułków w diecezji poznańskiej. Bardzo dużo z nich żyło z jałmużn i ofiar litościwych ludzi. Dodatkowe jałmużny na rzecz

${ }^{67}$ Tamże, s. 178-179, 183.

${ }^{68}$ Tak było w niektórych miastach diecezji poznańskiej w XVII i XVIII w. (Miejska Górka, Poznań, Śrem) Surdacki, Opieka społeczna, s. 182-183, 245.

${ }^{69}$ Tamże, s. 179; B. Maciejowski, Epistola pastoralis [...] 1601; Constitutiones synodales dioecesis Varmiensis [...] 1610.

${ }^{70}$ Mandziuk, Opieka społeczna Kościoła, s. 134.

${ }^{71}$ Góralski, Szpitale, s. 104-105.

72 Surdacki, Opieka spoleczna, s. 179-180; Reformationes generales [...] 1621; Synodus dioecesana Mednicensis [...] 1752; Constitiones et decreta [...] 1733, s. 118; Statuta synodalia dioecesis orthodoxae Kijoviensis [...] 1762; K.F. Szaniawski, Epistola pastoralis [...] 1720.

${ }^{73}$ Surdacki, Opieka spoleczna, s. 181; Synodus dioecesana [...] K. Eubieński [...] 1711. 
biednych pensjonariuszy w szpitalach nie posiadających żadnego stałego uposażenia płynęły również ze strony właścicieli dóbr i dziedziców ${ }^{74}$.

\section{b) dla żebraków spoza szpitali}

W przeciwieństwie do ubogich szpitalnych, których żebractwo było oficjalnie dozwolone, w gorszej sytuacji pozostawali nędzarze i ubodzy spoza szpitali. $\mathrm{W}$ okresie potrydenckim, żebranie ludzi nie kwalifikujących się do pobytu $\mathrm{W}$ szpitalach, a więc zdrowych, silnych i młodych oraz pochodzących $\mathrm{z}$ innych miejscowości czy parafii było zwalczane i zabronione ${ }^{75}$. Wyłom stanowiły w tej kwestii uchwały synodu lwowskiego z 1641 r., które pozwalały im żebrać poza szpitalami, o ile będą posiadać zezwolenie zaopatrzone $\mathrm{w}$ pieczęć państwową ${ }^{76}$. Pewnym wyjątkiem byli nędzarze i żebracy nie znajdujący schronienia w placówkach szpitalnych, lecz stowarzyszeni w bractwach ubogich, którym pozwalano legalnie prosić o jałmużny i przesiadywać, jak np. w wypadku żebraków z warszawskiej konfraterni ubogich przed kolegiatą św. Jana ${ }^{77}$. Z uwagi na trudność w zwalczaniu włóczęgostwa i żebractwa ubogich, sprawa ich selekcji i kwalifikowania do grupy uprawnionych do jałmużny, z racji na kalectwo, bądź podeszły wiek, była ciągle aktualna aż do końca przedrozbiorowej Rzeczypospolitej. W tej sytuacji król Stanisław Poniatowski w wydanym w 1786 r. uniwersale nakazał, by po wyodrębnieniu z tłumu żebraków i osób rzeczywiście potrzebujących pomocy i sporządzeniu ich spisu, każda parafia i każda miejscowość utrzymywała ubogich własnym kosztem. Mieli o to zadbać rządcy parafii oraz urzędy miejskie. Jeszcze w tym samym roku biskup wileński Ignacy Massalski ogłosił powyższy uniwersał w swojej diecezji, polecając, by plebani wzywali wiernych do udzielania pomocy prawdziwym ubogim, po wcześniejszym zaopatrzeniu ich w odpowiednie znaki i zaświadczenia uprawniające do zbierania jałmużny. Jednocześnie wezwał, by żebrakom silnym i zdrowym poszukać uczciwej pracy ${ }^{78}$.

Jałmużnę jako formę wspierania ubogich, zanegowała całkowicie reformacja. Jako przykład może tu służyć Gdańsk, gdzie luterańska rada miejska wydając w 1524 r. rozporządzenie antyżebracze, piętnowała zwyczaje wytworzone w czasie średniowiecza. Od tego czasu nakazywano zaniechać rozdawania jałmużny przed drzwiami domów przez osoby prywatne z okazji pogrzebów, chrztów i ślubów ${ }^{79}$.

Mimo głoszonych zakazów, anonimowe masy prawdziwych żebraków i ubogich, żyjących poza szpitalami, zmuszone były korzystać z mającego średniowieczne tradycje indywidualnego jałmużnictwa. Aktywne na tym polu były

${ }^{74}$ Surdacki, Opieka spoteczna, s. 245-246.

${ }^{75}$ Tamże, s. 180, 183.

${ }^{76}$ Synodus dioecesana Leopoliensis [...] 1741.

${ }^{77}$ Karpiński, Pauperes, s. 323-324. Problem żebrania i zbierania jałmużny przez ubogich z poza szpitali omówiony został w Rozdziale VIII.

${ }^{78}$ T. Kasabuła, ,,Proces do Dyecezyi i względem ubogich” biskupa wileńskiego Ignacego Massalskiego z dnia 17 XII 1786 roku, „Wiadomości Kościelne Archidiecezji Białostockiej”, 9 (28), 2000, nr 1 (116), s. 194.

${ }^{79}$ Z. Kropidłowski, Dzieje miłosierdzia chrześcijańskiego w średniowiecznym Gdańsku, „Universitatis Gedanensis", 3 (1991) nr 5, s. 44. 
szczególnie kobiety, które często obejmowały opieką konkretnych biedaków, regularnie, nieraz codziennie obdzielając ich jałmużną, posiłkami czy zapewniając higienę ${ }^{80}$. Zakres i skala jałmużnictwa indywidualnego $\mathrm{w}$ stosunku personae mendicae ${ }^{81}$, musiała być ogromna i trudno porównywalna $\mathrm{z}$ innymi formami działań dobroczynnych, w tym instytucjonalnych. To, że jałmużna indywidualna, stanowiła zjawisko ilościowo niemożliwe do określenia i sprawdzenia, było konsekwencją praktycznego stosowania przez wiernych ewangelicznej zasady definiującej formy i sposoby jej udzielania, mówiące, że prawdziwa jałmużna nie powinna być przez dawcę manifestowana ale ukryta.

Dogodną okazję do zbierania jałmużny stwarzały uroczyste nabożeństwa, urządzane z okazji większych świąt kościelnych i wydarzeń państwowych. Duże możliwości do zbierania datków i ofiar dawały miejsca odpustowe oraz ośrodki kultu religijnego, do których zawsze ciągnęły ogromne rzesze nędzarzy i żebraków ${ }^{82}$. Sprzyjającą okoliczność do zdobycia przez żebraków jałmużny, a nawet fundowania im obiadów, stanowiły też uroczystości i wydarzenia rodzinne: śluby, narodziny potomka - chrzciny, msze za zmarłych, pogrzeby i stypy ${ }^{83}$.

Dawanie jałmużn przyjmowało różny charakter. $Z$ reguły czyniono to spontanicznie, nieregularnie, najczęściej jednorazowo. Rzadziej spotykało się jałmużny świadczone cyklicznie, choćby comiesięcznie. Na takie praktyki pozwalali sobie ludzie bogatsi, np. magnateria. Charytatywno-jałmużniczy mecenat na biedakami zamieszkującymi teren rozległych dóbr ordynackich, sprawowali przedstawiciele rodu Zamoyskich. Za czasów Jana Zamoyskiego w księdze wydatków z lat 1579-1582 znajdował się odrębny dział zatytułowany Pia opera, w którym rejestrowano wszelkie jałmużny wypłacane z kasy kanclerza swym poddanym oraz szpitalom. Comiesięczną jałmużnę wypłacali też ordynaci w ostatnim dziesięcioleciu XVIII w. inwalidom, kalekim żołnierzom, biednym kobietom. Ze wsparcia dworu zamojskiego w postaci renty czy pensji miesięcznej, korzystały też kobiety wywodzące się z wyższych warstw społecznych - z reguły szlacheckie wdowy po urzędnikach dworskich i ordynackich. Swego rodzaju jałmużną było pokrywanie przez Zamoyskich z własnej kasy kosztów pogrzebu, zwłaszcza ludzi zasłużonych w służbie ordynackiej lub też ludzi biednych przebywających w szpitalach ${ }^{84}$.

Formy wspierania żebraków zależały od środowisk i miejsc, z których się wywodzili, lub w których czasowo gościli w celach zarobkowych czy dla pozyskania jałmużny. Mnóstwo było bowiem nędzarzy wędrownych, przemieszczających się między miastami i wsiami ${ }^{85}$. Problemem dla nich było nie tylko zdobycie jałmużny, ale też ewentualnego schronienia i dachu nad głową, zwłaszcza podczas zimy. Ludność wiejska udzielała pomocy żebrakom najczęściej poprzez darowanie im

${ }^{80}$ Karpiński, Kobieta, s. 238-240.

${ }^{81}$ Surdacki, Opieka spoleczna, s. 179.

${ }^{82}$ Budzyński, Dzieje opieki, s. 162.

${ }^{83}$ Partyka, Opieka społeczna, s. 220, 243-244; Mandziuk, Opieka społeczna Kościoła, s. 135

${ }^{84}$ Partyka, Opieka spoleczna, s. 220-223, 225-226, 245.

${ }^{85} \mathrm{O}$ żebrakach miejscowych i obcych w mieście Urzędowie: M. Surdacki, Urzędów w XVII i XVIII wieku. Miasto-społeczeństwo-życie codzienne, Lublin 2007, s. 73-74-510. Por. S. Cynarski, Ze studiów nad ludnościa miasta Krosna w XVI-XVIII w., „Rocznik Przemyski”, 11 (1967) s. 83. 
posiłku, zbędnej odzieży lub noclegu, z reguły w jakimś pomieszczeniu gospodarczym, oborze, chlewie lub stodole ${ }^{86}$. Większe możliwości uzyskania jałmużny posiadali żebracy w miastach. Wiele domów mieszczańskich miało swoich stałych klientów: biedaków oczekujących przy drzwiach na pomoc. Bogatsi żebracy gromadzili się na noc w karczmach i gospodach, większość jednak szukała noclegu w stajniach, opuszczonych domostwach i basztach, podcieniach w rynku oraz w bramach miejskich i kamienic ${ }^{87}$. W większych miastach żebracy mieszkali w różnych przedmiejskich lepiankach. Zaś w ciągu dnia zalegali wejścia do ważniejszych budynków publicznych i kościelnych, oczekując na jałmużny od dobrodziejów ${ }^{88}$.

Repertuar forteli i zabiegów stosowanych przez żebraków i ubogich w celu wzbudzenia u ofiarodawcy miłosierdzia i skutecznego uzyskania jałmużny był niezwykle szeroki i wymyślny. Jednym z nich było celowe okaleczanie się, symulowanie kalectwa lub imitowanie, poprzez różne mazidła, chorób, np. gangreny czy chorób skórnych. W uprawianiu tego procederu żebracy wykorzystywali też często swoje dzieci lub sieroty włóczące się po ulicach ${ }^{89}$. Podobne sztuczki stosowały nawet siostry zakonne. W XIV w beginki świdnickie specjalnie pościły, powstrzymywały się od snu i puszczały sobie krew, aby swoim niezdrowym i ascetycznym względem zyskiwać większe współczucie i hojność dobroczyńców. Zapraszały też do klasztoru swoje dobrodziejki, a następnie częstowały je najgorszym jadłem, skarżąc się, że z powodu ubóstwa nie stać je na lepsze. Taka demonstracja nie pozostawała bez wpływu na szczodrobliwość odwiedzających je mieszczanek ${ }^{90}$.

\section{Jałmużna pogrzebowa}

Tak jak agapy i spotkania organizowane przy okazji pochówków w czasach pierwotnego chrześcijaństwa, również w późniejszych epokach ceremonie pogrzebowe, zwłaszcza ludzi zamożnych posiadały cechy wydarzenia dobroczynnego, które dawało biednym i żebrakom okazję do uzyskania jałmużny lub przynajmniej pożywienia. Akt miłosierdzia w stosunku do ubogich i potrzebujących na wypadek śmierci był często z góry zaplanowany w testamentach, jeszcze za życia fundatora czy testatora.

W ówczesnej mentalności istniał ścisły związek między liturgią pogrzebową a jałmużną, wkalkulowaną w koszty pogrzebu ${ }^{91}$. U schyłku średniowiecza w diecezji wrocławskiej dyspozycje jałmużnicze przyjmowały charakter fundacji i posiadały symboliczną biblijną wymowę. Często spotykano tam różne formy świadczeń dla grupy obejmującej apostolską liczbę 12 lub 13 osób. We Wrocławiu, Nysie, Opolu czy Brzegu w XV wieku jeszcze za życia niektórzy mieszczanie

${ }^{86}$ Budzyński, Dzieje opieki, s. 161; Partyka, Opieka społeczna, s. 234.

${ }^{87}$ Budzyński, Dzieje opieki, s. 162; Cynarski, Ze studiów, s. 83.

${ }^{88}$ Budzyński, Dzieje opieki, s. 162.

${ }^{89}$ Praktyki te szeroko i sugestywnie opisuje B. Geremek, Świat opery żebraczej. Obraz włóczęgów i nędzarzy w literaturach europejskich XV-XVII wieku, Warszawa 1989; tenże, Ludzie marginesu, s. 194-196. Zob. też: Dola, Opieka spoleczna i zdrowotna, s. 119.

${ }^{90}$ Wółkiewicz, Formy dobroczynności, s. 225-226.

${ }^{91}$ Tamże, s. 212. 
życzyli sobie, aby gdy umrą, w dzień po ich śmierci, lub nawet codziennie przez cały rok goszczono $\mathrm{i}$ żywiono 12 nędzarzy. Jedna $\mathrm{z}$ fundacji testamentowych przewidywała fundusz dla 12 ubogich, którzy w każde Suche Dni mieli zasiąść do wspólnego posiłku, a następnie otrzymać po parze butów i kawałku sukna na ubranie ${ }^{92}$. Utrwalonym zwyczajem było również połączenie rozdawnictwa jałmużny z rocznicą śmierci, dniem Wszystkich Świętych czy innym związanym z pamięcią o zmarłych ${ }^{93}$. Ubodzy stawali się pożądanymi uczestnikami nabożeństw kommemoracyjnych, odprawianych $\mathrm{w}$ rocznicę zgonu. W zamian za udział $\mathrm{w}$ mszach rocznicowych mieli oni wypłacane pewne kwoty, zapisane wcześniej na ten cel przez żyjącego jeszcze wtedy fundatora ${ }^{94}$.

Praktyki świadczenia jałmużny i posiłków dla ubogich powszechne były również na terenach całej Rzeczypospolitej w czasach nowożytnych. Dobrym zwyczajem była obecność żebraków na pogrzebach znaczniejszych osób, o co ci ostatni sami zabiegali jeszcze za życia. Uczestnictwo w egzekwiach oraz modłach za zmarłą duszę wynagradzano niewielkimi datkami pieniężnymi, bądź „obiadem pogrzebowym" czyli stypą fundowaną dla żebraków i pensjonariuszy szpitalnych, uczestniczących w uroczystościach funeralnych. Koszty ponoszone na te cele wynosiły od kilku do kilkudziesięciu złotych, za które można było ugościć nawet 30 nędzarzy jednorazowo ${ }^{95}$. „Obiady pogrzebowe” czy stypy nazywano niekiedy „bożym obiadem”96. Stypy, początkowo skromne, z czasem coraz bardziej wystawne, połączone były z drobnymi datkami pieniężnym oraz z kąpielą żebraków, opłacaną przez darczyńcę ${ }^{97}$. Niespotykaną hojność wykazał Mikołaj Spytko Ligenza (Ligęza), który przewidując, iż w jego pogrzebie weźmie udział ok. 500 żebraków, nakazał ich po swym pogrzebie ugościć i obdarzyć jednozłotową jałmużną. Podobne sformułowania zawierało większość testamentów, szlachty, duchownych jak i mieszczan ziemi przemyskiej i sanockiej ${ }^{98}$.

\section{Jałmużna instytucjonalna}

\section{Jalmużna klasztorno-szpitalna}

Nie mniej ważna niż jałmużna prywatna i indywidualna, była jałmużna instytucjonalna, np. szpitalna bracka czy klasztorna. Była ona ilościowo słabiej rozpowszechniona, ale za to dawała większe możliwości organizacyjne i materialne. Szpitale nie tylko korzystały z jałmużny dawanej na rzecz tych instytucji przez osoby prywatne, lecz niektóre z nich, zwłaszcza zakonne, korzystając z solidnych

\footnotetext{
${ }^{92}$ Tamże, s. 223-224.

${ }^{93}$ Tamże, s. 224.

${ }^{94}$ Tamże, s. 212.

${ }^{95}$ Karpiński, Kobieta, s. 249-250.

${ }^{96}$ Głowacka-Penczyńska, Testamenty mieszkańców, s. 389; taż, Kobieta w matych miastach Wielkopolski w drugiej połowie XVI i w XVII wieku, Warszawa 2010, s. 105; A. Głowacka, Dobroczynność w obliczu śmierci w małych miastach wielkopolskich $w$ drugiej połowie XVI $i$ w XVII wieku, w: Choroba i śmierć w perspektywie społecznej w XIII-XXI wieku, red. D.K. Chojecki, E. Włodarczyk, Warszawa 2010, s. 97-98.

${ }^{97}$ Karpiński, Kobieta, s. 250-251; tenże, Pauperes, s. 347.

${ }^{98}$ Przyboś, Rzeszów, s. 117; Budzyński, Dzieje opieki, s. 162, 166.
} 
podstaw materialnych, same świadczyły jałmużnę dla osób potrzebujących z zewnątrz.

Rozdawaniem jałmużny u bram klasztornych zajmowało się większość zakonów, chociażby benedyktyni, u których zwyczaj ten sięgał jeszcze początków drugiej połowy pierwszego milenium chrześcijaństwa ${ }^{99}$. Reguły zakonne nakazywały furtianom szczególną troskę o ludzi, którzy w jakiejkolwiek potrzebie zwrócą się o pomoc ${ }^{100}$. Opactwa benedyktyńskie sumiennie realizowały ten nakaz, udzielając ubogim różnorodnych jałmużn w Tyńcu, Sieciechowie i na Łysej Górze ${ }^{101}$, a także w Toruniu, gdzie benedyktynki wspomagały jałmużną pieniężną ubogich przychodzących do bramy klasztornej ${ }^{102}$. Mnisi benedyktyńscy kontynuowali tę formę miłosierdzia i w wiekach późniejszych. $\mathrm{Z}$ ich pomocy korzystali często mieszkańcy szpitali zlokalizowanych w dobrach zakonnych. W 1724 r. klasztor w Obrze wydawał codziennie wikt żebraczy dla jednego z ubogich pensjonariuszy tamtejszego szpitala ${ }^{103}$. Przez całe osiemnaste stulecie różnego rodzaju jałmużn wyczekiwali u furt klasztorów benedyktyńskich biedni przebywający w szpitalach w Przemęcie i Lubiniu ${ }^{104}$. Mogły też różne grupy pauperes otrzymać jednorazowe wsparcie u bram kościołów parafialnych czy wrót szpitalnych ${ }^{105}$.

Systematyczne żywienie ubogich u furt klasztornych praktykowały opactwa cysterskie (Trzebnica, Henryków, Lubiąż, Kamieniec, Pelplin, Oliwa), klasztory norbertanów (Wrocław), kanoników regularnych św. Augustyna (Nowogród, Żagań) czy joannitów ${ }^{106}$. Jeden z biskupów średniowiecznych nakazywał cystersom w Kamieńcu, by podtrzymywali „starożytny zwyczaj cotygodniowego rozdawania hojnych jałmużn biednym przychodzącym z całej okolicy"107. Zakrojone na szeroką skalę jałmużnictwo praktykowano w średniowieczu w szpitalu św. Idziego we Wrocławiu czy szpitalach zakonnych bożogrobców ${ }^{108}$. Akt fundacji nowego szpitala bożogrobców w Rypinie z 1349 r. przewidywał, że nadwyżki dochodów

${ }^{99}$ V. Paglia, Storia dei poveri, Milano 1994, s. 116-140, 158-172.

${ }^{100}$ Dola, Opieka społeczna i zdrowotna, s. 120.

${ }^{101}$ Tenże, Opieka społeczna Kościoła, t. I, cz. 1, s. 168; M. Derwich, Benedyktyński klasztor św. Krzyża na Łysej Górze w średniowieczu, Warszawa-Wrocław 1992, s. 536-537.

102 J. Fankidejski, Klasztory żeńskie diecezji chetmińskiej, Pelplin 1883, s. 126, 129, 130.

${ }^{103}$ Surdacki, Opieka społeczna, s, 246.

${ }^{104}$ Tamże, s. 246.

${ }^{105}$ Karpiński, Pauperes, s. 348; Dola, Opieka spoleczna i zdrowotna, s. 120.

${ }^{106}$ Dola, Opieka społeczna Kościoła, t. I, cz. 1, s. 168-169; tenże, Szpitale średniowieczne Ślaska. Rozwój historyczny, „Rocznik Teologiczny Śląska Opolskiego”, 1 (1968) s. 242, J. Fankidejski, Utracone kościoły i kaplice $w$ dzisiejszej diecezji chetmińskiej podtug urzędowych akt kościelnych, Pelplin 1880, s. 197; S. Kujot, Opactwo pelplińskie, Pelplin 1875, s. 208, 213-214; K. Dąbrowski, Opactwo cystersów w Oliwie od XII do XVI wieku, Gdańsk 1975, s. 171-173; tenże, Działalność społeczna cystersów w Oliwie w XII-XVI wieku, „Summarium”, 23 (1974) nr 3, s. 134; J. Mandziuk, Historia Kościoła Katolickiego na Śląsku, t. 1, cz. 2, Warszawa 2004, s. 105.

${ }^{107}$ K. Dola, Szpitale średniowieczne Śląska. Rozwój historyczny, „Rocznik Teologiczny Śląska Opolskiego", 1 (1968) s. 242.

${ }^{108}$ Tamże, s. 242, 253. 
w wypadku braku podopiecznych mają być rozdawane jako jałmużna ${ }^{109}$. Z kolei u joannitów istniał zwyczaj rozdawania pożywienia przez trzy dni w tygodniu, oraz dawania monet ubogim w rocznicę zgonu lub pogrzebu braci zakonnych ${ }^{110}$.

W czasach nowożytnych świadczeniem tej formy pomocy biednym z poza szpitali zajmowały się przede wszystkim siostry szarytki, które Maria Ludwika Gonzaga sprowadziła do Polski, m.in. po to, by rozdawały jałmużnę ${ }^{111}$. Powinność tę wykonywały nie tylko w placówce warszawskiej, ale też po wielu innych swoich domach ${ }^{112}$. W rozdawnictwie jałmużny przejawiał się również charytatywny charyzmat u misjonarzy, powiązanych organizacyjnie z szarytkami. Szczególnym miłosierdziem zakonnicy odznaczyli się w 1652 r. podczas szalejącej w kraju epidemii dżumy, kiedy rozdawali jałmużnę zakażonym morowym powietrzem $^{113}$. Wraz z obiadami wydawali ją również biednym $\mathrm{w}$ spokojniejszych już czasach w następnym stuleciu w Wilnie ${ }^{114}$. Różnorodnej jałmużny dla biednych w czasach staropolskich nie szczędziły wszystkie inne zakony, choćby jezuici ${ }^{115}$.

\section{Jałmużna bracka}

Ważnym źródłem, z którego biedni czerpali jałmużnę były bractwa charytatywne. Rozdawanie różnego rodzaju datków i zapomóg osobom znajdującym się w trudnych sytuacjach życiowych było głównym celem tych organizacji ${ }^{116}$. Takie zadania wpisane były w statuty i regulaminy wszystkich bractw miłosierdzia propagowanych i zakładanych przez Piotra Skargę. Członkowie krakowskiego oraz warszawskiego bractwa miłosierdzia zobowiązani byli do obdarowywania co tydzień dobrowolną jałmużną biedaków miejskich, jak i osób przebywających w szpitalach i więzieniach ${ }^{117}$. Bractwo krakowskie, wobec wielokierunkowej

${ }^{109}$ M. Starnawska, Między Jerozolimą. Zakony krzyżowe na ziemiach polskich w średniowieczu, Warszawa 1999, s. 233.

${ }^{110}$ Mandziuk, Opieka społeczna Kościoła, s. 134.

${ }^{111}$ B. Fabiani, Ludwika Maria i Francuzi w Warszawie 1646-1668, w: Warszawa XVI-XVII wieku, Warszawa 1977, s. 233.

112 A. Schletz, Zarys historyczny zgromadzenia sióstr miłosierdzia w Polsce, „Nasza Przeszłość", 12 (1960) s. 75-76.

${ }^{113}$ Księga pamiątkowa trzechsetlecia zgromadzenia księży misjonarzy (1625-1925), Kraków 1925, s. 68; M. Świątecka, Św. Wincenty a Polska, „Nasza Przeszłość”, 11 (1960) s. 49; Misjonarze św. Wincentego a Paulo w Polsce (1651-2001), I. Dzieje, red. S. Rospond, Kraków 2001, s. 5.

114 Salwa, Litewska prowincja, s. 225-226; Ksiega pamiatkowa, s. 116; J. Kurczewski, Biskupstwo wileńskie, Wilno 1912, s. 361; M. Kolankiewicz, Historia Domu Małych Dzieci ks. G. P. Baudouina, Warszawa 1997, s. 15; J. Maroszek, Wileńskie przytulki-szpitale w XVI-XVIII wieku, w: Cała historia to dzieje ludzi... studia z historii społecznej ofiarowane prof. Andrzejowi Wyczańskiemu w 80. rocznice urodzin i 55-lecie pracy naukowej, red. C. Kuklo, Białystok 2004, s. 215-216.

${ }^{115}$ Mandziuk, Opieka społeczna Kościoła, s. 134. Zob. rozważania o działalności charytatywnej zakonów.

${ }^{116}$ Szerzej o tym w Rozdziale VIII. [tytuł publikacji]

${ }^{117}$ S. Chodyński , Bractwo, w: Encyklopedia Kościelna, t. 2, wyd. M. Nowodworski, Warszawa 1873, s. 574; Kumor, Kościelne stowarzyszenia, s. 520-521; K. Jelonek-Litewka, Arcybractwo Miłosierdzia i Banku Pobożnego w Krakowie, „Nasza Przeszłość”, 61 (1984) s. 50, s. 67; Karpiński, Pauperes, s. 315; Giedroyć, Rys historyczny szpitala, s. 9, 26-27. 
działalności dobroczynnej, posiadało nawet specjalnie wydzielony fundusz jałmużniczy ${ }^{118}$. Udzielaniem jałmużny dla ubogich oraz zakupem drzewa i odzieży czy dostarczaniem trumien dla zmarłych ubogich zajmowała się też poznańska konfraternia ubogich ${ }^{119}$. Funkcjonowała ona jeszcze w dobie rozbiorów Polski, rozdając jałmużny i zapomogi sierotom, wdowom, zubożałym szlachciankom, neofitkom czy pensjonariuszkom szpitalnym ${ }^{120}$.

Nie mniej ważne miejsce zajmowała jałmużna w bractwach miłosierdzia reaktywowanych w latach 70. XVIII w. przez bpa Michała Jerzego Poniatowskiego. Stanowiła ona zarówno źródło dochodów konfraterni, jak też po jej zgromadzeniu, środek wspomagania potrzebujących ${ }^{121}$. Do cotygodniowego jej przekazywania ubogim, zobowiązywali się konfratrzy już w momencie wstępowania do stowarzyszenia $^{122}$. Świadczenie jałmużny było też podstawowym środkiem zaspokajającym potrzeby ubogich w koncepcji bractw miłosierdzia, proponowanej przez biskupa inflanckiego, a następnie wileńskiego, Józefa Kazimierza Kossakowskiego ${ }^{123}$.

Obowiązek rozdawania jałmużny występował również w statutach niektórych bractw dewocyjnych, np. w konfraterniach literackich w Nowym Sączu i Poznaniu $^{124}$ czy też w Bractwie Bożego Ciała w Wilnie ${ }^{125}$.

\section{Jałmużna biskupia, monarsza, miejska}

Trudno jednoznacznie określić dobroczynność i jałmużnictwo ze strony biskupów czy monarchów. $Z$ jednej strony występowali oni jako indywidualni dawcy jałmużny, $z$ drugiej reprezentowali majestat władzy i pełnione przez siebie urzędy państwowe bądź kościelne, dysponowali przy tym środkami niekoniecznie prywatnymi. Wśród hierarchów Kościoła łacińskiego szczególną aktywnością do-

${ }^{118}$ Kumor, Kościelne stowarzyszenia, s. 525; tenże, Kościelne stowarzyszenia, s. 325; K. Jelonek-Litewka, Arcybractwo Miłosierdzia, s. 75-76.

${ }^{119} \mathrm{~J}$. Łukaszewicz, Krótki opis historyczny kościołów parochialnych, kościołów, kaplic, klasztorów, szkółek parochialnych, szpitali i innych zakładów dobroczynnych dawnej diecezji poznańskiej, t. 1, Poznań 1958, s. 151.

${ }^{120}$ C. Kuklo, Kobieta samotna w społeczeństwie miejskim u schyłku Rzeczypospolitej szlacheckiej, Białystok 1998, s. 197-202; A. Markwitzówna, Bractwo Miłosierdzia w Poznaniu w XVIII w., „Kronika miasta Poznania”, 2 (1948) s. 121, 124.

${ }^{121}$ M.J. Poniatowski, Ustanowienie Bractwa Miłosierdzia po parafiach $w$ dyecezyi płockiey, Warszawa 1777, s. 14-15; tenże, Ustanowienie Bractwa Miłosierdzia po parafiach archi-diecezyi gnieźnieńskiey, Łowicz 1787, tenże, Ustanowienie Bractwa Miłosierdzia po parafiach $w$ dyecezyi krakowskiey, Warszawa 1784, s. 16-17.

${ }^{122}$ M. Grzybowski, Kościelna działalność Michała Jerzego Poniatowskiego biskupa płockiego 1773-1785, w: Studia z historii Kościoła w Polsce, t. 7, Warszawa 1983, s. 182, s. 19-23.

${ }^{123}$ J.K. Kossakowski, Xiadz pleban, Warszawa 1786, s. 90-92, 140-141.

${ }^{124}$ B. Kumor, Statuty Bractwa Literackiego Nauki Chrześcijańskiej przy kolegiacie św. Matgorzaty w Nowym Saczu, „Archiwa, Biblioteki i Muzea Kościelne”, 2 (1961) s. 362, 376-377; J. Flaga, Działalność charytatywna bractw religijnych w XVII i XVIII wieku, w: Ecclesia et Status. Ksiega jubileuszowa z okazji 40-lecia pracy naukowej Profesora Józefa Krukowskiego, red. A. Dębiński, K. Orzeszyna, M. Sitarz, Lublin 2004, s. 390; Kuklo, Kobieta samotna, s. 212-213.

${ }^{125}$ Kurczewski, Biskupstwo, s. 367. 
broczynną wyróżniał się biskup przemyski Wacław Hieronim Sierakowski, któremu ubodzy towarzyszyli w czasie każdej podróży. W Wielki Czwartek przyjmował w swojej rezydencji 13 żebraków, obdarzał jałmużną i obiadem, w czasie którego usługiwał im przy stole ${ }^{126}$. Z kolei z przejawem dobroczynności ze strony członków rodziny królewskiej można się było spotkać na dworze Marii Ludwiki, na którym codziennie rozdawano obfite jałmużny ze skarbu królewskiego oraz rozdzielano pomiędzy ubogich pożywienie z monarszego stołu ${ }^{127}$.

Do zorganizowanych i instytucjonalnych form wspierania ubogich należały katolickie fundusze jałmużnicze (zwane ,wieczystymi”), tworzone przy niektórych parafiach ze składek wiernych. Istniały one w Głogowie; pierwszy od XV w. przy kolegiacie Najświętszej Maryi Panny na Ostrowie, inny od początku XVI w. przy kościele pw. św. Mikołaja. Wzorem dla nich mogły być rozwiązania protestanckie, tym bardziej, że drugi z wymienionych kościołów znajdował się w tym czasie (1581-1638) w ręku luteranów ${ }^{128}$.

Inicjatywami instytucjonalnymi były wszelkie formy wspierania ubogich, poprzez przydzielanie zasiłków i datków, organizowane przez władze miejskie. Władze magistrackie siedemnastowiecznej Warszawy corocznie wydawały pewne kwoty pieniężne na stałe lub doraźne jałmużny. Akcje te nasilały się w okresie klęsk elementarnych, szczególnie w czasie pomoru dżumy. Obok pieniężnych zapomóg, dostarczano również izolowanym chorym i błąkającym się po ulicach ubogim artykuły żywnościowe ${ }^{129}$. W czasie zarazy w latach $1624-1625$ jałmużny i zapomogi z magistratu otrzymywali zubożali rzemieślnicy, następnie biedniejsze wdowy, rodziny wielodzietne, starcy i kaleki, sieroty i podrzutki, słudzy miejscy i prywatni, włóczędzy. Nędzarze byli głównym adresatem datków i jałmużn pogrzebowych. $Z$ rzadsza władze Warszawy obdarowywały jednorazowymi darowiznami weselnymi ubogich funkcjonariuszy magistratu, przydzielały datki chorobowe, odszkodowania i zasiłki inwalidzkie za utratę zdrowia pracownikom miejskim. Poza licznymi szpitalami, w akcję pomocy bliźnim ofiarnie włączały się zamożniejsze warstwy społeczne, tworząc różnego rodzaju fundacje zapomogowe, posagowe, stypendialne, czynnie uczestnicząc w działalności brackiej, czy wreszcie indywidualnych akcjach jałmużniczych. Brak było natomiast ściślejszej koordynacji działań na polu dobroczynnym między władzami kościelnymi, miejskimi czy królewskimi ${ }^{130}$.

Podobną pomoc ubogim i żebrakom, choć na mniejszą skalę, proporcjonalną do liczby ludności, organizowały władze magistrackie innych miast. Działo się tak również w miastach prywatnych, np. w Zamościu i Kraśniku, w których magistrat był $\mathrm{w}$ tej powinności często wyręczany przez dwór. Mimo to w obu ośrodkach miejskich, z budżetu publicznego opłacano pochówki najuboższych, wspierano ubogich jednorazowymi lub regularnymi jałmużnami i zapomoga-

126 J. Ataman, Wacław Hieronim Sierakowski i jego rządy w diecezji przemyskiej, Warszawa 1936, s. 198-199; Budzyński, Dzieje opieki, s. 162.

${ }^{127}$ Karpiński, Pauperes, s. 348; Fabiani, Ludwika Maria, s. 233.

${ }^{128}$ Dola, Opieka spoteczna i zdrowotna, s. 121-122, 145.

${ }^{129}$ Karpiński, Pauperes, s. 335-339.

${ }^{130}$ Tamże, s. 240-243, 350. 
$\mathrm{mi}^{131}$. Świadectwem zbiorowej solidarności mieszkańców z najbiedniejszymi jest uchwała magistratu sandomierskiego z 1635 r., wedle której należało wypłacać 12 groszy tygodniowo każdemu mieszczaninowi będącemu w biedzie ${ }^{132}$.

Niektóre miasta tworzyły specjalne fundusze charytatywne na pomoc ubogim. Składały się na nie drobne sumy płynące z dobroczynności chrześcijańskiej, jak też grzywny pieniężne nakładane na mieszczan za nieprzestrzeganie statutów miejskich. W ten sposób w Głogowie na Śląsku w XV-XVI w., powstawała instytucja przypominająca kasę ubogich, rozpropagowaną później przez środowiska luterańskie. Nie przewidywano tam natomiast wydatków na wsparcie dla ubogich z funduszu kasy miejskiej. Zaczęto to czynić dopiero w dwu następnych stuleciach. Na polecenie nowych władz pruskich utworzono w Głogowie nawet kasę ubogich na czele $\mathrm{z}$,przełożonym ubogich” oraz trzema wójtami żebraczymi ${ }^{133}$. Do zorganizowanych form świadczenia wsparcia zaliczyć należy prowadzenie w tym czasie w niektórych miastach śląskich (np. w Nysie) list ubogich, którzy otrzymywali stałą jałmużnę ${ }^{134}$.

\section{Jalmużna $z$ kar sądowych}

Ważnym źródłem wspierania ubogich i płynącej do nich jałmużny były dochody z wszelkiego typu kar, zarówno sądowych, jak i nakładanych w innych okolicznościach. Chodzi tu między innymi o klauzule charytatywne umieszczane w testamentach nakładających na księży sankcje za niedopełnienie woli fundatora dotyczącej np. zorganizowania uroczystego pogrzebu i pochówku fundatora czy nie wypełnienie intencji mszalnych za jego duszę. W takich wypadkach, opieszali lub nieuczciwi duchowni zobowiązani byli zapisane sumy lub swoje wynagrodzenie przekazywać na potrzeby ubogich ${ }^{135}$. Na synodzie w Piotrkowie w $1539 \mathrm{r}$. uchwalono, że dochody z kar pieniężnych nakładanych na „występnych” księży miały być przeznaczane $m$.in. na jałmużnę $e^{136}$.

Przeznaczanie dochodów z kar na biednych wynikało ze średniowiecznej koncepcji Caritas, która była jedną z elementarnych praktyk pokutnych ${ }^{137}$. Czynienie miłosierdzia stawało się warunkiem zadośćuczynienia za popełnione cięż-

${ }^{131}$ Partyka, Opieka społeczna, s. 244-245.

${ }^{132} \mathrm{~W}$. Kowalski, Opieka społeczna i dobroczynność na terenie archidiakonatu sandomierskiego $w$ dobie przedrozbiorowej, w: Charitas. Mitosierdzie i opieka społeczna $w$ ideologii, normach postępowania i praktyce spoleczności wyznaniowych w Rzeczypospolitej XV-XVIII wieku, red. U. Augustyniak, A. Karpiński, Warszawa 1999, s. 183.

${ }^{133}$ Dola, Opieka spoteczna i zdrowotna, s. 121-122.

${ }^{134}$ J. Mandziuk, Historia Kościoła katolickiego na Śląsku, t. 2, Warszawa 1995, s. 215; tenże, Opieka społeczna Kościoła, s. 134.

${ }^{135}$ Wółkiewicz, Formy dobroczynności, s. 213.

${ }^{136}$ K. Karaskiewicz, Teoria mitosierdzia wedlug prymasa Michała Jerzego Poniatowskiego na podstawie jego listów, w: Charitas. Miłosierdzie i opieka społeczna w ideologii, normach postępowania i praktyce spoleczności wyznaniowych w Rzeczypospolitej XV-XVIII wieku, red. U. Augustyniak, A. Karpiński, Warszawa 1999, s. 33. Zob. I. Subera, Synody prowincjonalne arcybiskupów gnieźnieńskich, Warszawa 1981, s. 89.

${ }^{137}$ Dola, Opieka społeczna i zdrowotna, s. 119-120. 
kie przestępstwa, zwłaszcza zabójstwo. W okresie późnego średniowiecza, oprócz opłacenia świadczeń modlitewnych za duszę zabitego, od przestępcy oczekiwano fundacji posiłków, ubrań i łaźni dla nędzarzy, a przede wszystkim rekompensaty dla rodziny ofiary ${ }^{138}$.

Jałmużna mająca duże znaczenie jako czyn pokutny świadczony dla wyrównania własnych grzechów, stanowiła jedną z najczęstszych form zadośćuczynienia zadawanego przez spowiedników penitentom. Utrzymywanie ubogiego lub podjęcie innych aktów miłosierdzia, w nakazach pokutnych skierowanych do grzeszników, było w średniowieczu i czasach nowożytnych, nie tylko środkiem odpuszczenia win ale też świadomym działaniem dobroczynnym. Toteż wiele bull papieskich i dekretów biskupich przyznających wiernym odpusty obok skruchy i pokuty sakramentalnej wymienia jałmużnę jako warunek przebaczenia grzechów i uzyskania odpustu ${ }^{139}$.

W okresie staropolskim wpływy z grzywien i kar normowane były przepisami prawnymi, a często wynikały z prawa zwyczajowego. Dochody z grzywien nakładanych przez sądy wójtowskie i radzieckie czerpały często szpitale w mniejszych miejscowościach i miasteczkach Lubelszczyzny, szczególnie z procesów z procesów o cudzołóstwo. Rzadsze były dochody na szpitale i ich pensjonariuszy $\mathrm{z}$ kar zasądzanych w procesach o kradzieże, dyfamacje czy pobicie ${ }^{140}$. W Lublinie na cele szpitalne i dobroczynne przeznaczane były vadia ustanawiane w sporach między rzemieślnikami - mistrzami i ich czeladnikami lub uczniami ${ }^{141}$.

W Urzędowie sądy często zasądzały, aby grzywny pieniężne obwiniony przekazał jako zadośćuczynienie na potrzeby szpitala bądź „na ubóstwo szpitala”. Niekiedy ferowane kary przeznaczano bezpośrednio na biednych, choć nie do końca wiadomo, czy żyjących w przytułku, czy też ubogich poza szpitalnych. Zdarzało się, że zadośćuczynienie pieniężne wyznaczone przez sąd za poniesione szkody sam poszkodowany przeznaczał na ubogich i szpital. Uczynił tak w 1622 r. szlachcic, wyznawca arianizmu, Krzysztof Lubieniecki, który 100 grzywien odszkodowania za pobicie, na „różne ubogie rozdał”, w tym 20 grzywien przekazał szpitalowi urzędowskiemu dla ubogich. Darowane fundusze ofiarował też w części szpitalowi ariańskiemu w Rakowie, pogorzelcowi, podróżnemu, białogłowie ze szpitala rakowskiego oraz starej, ubogiej kobiecie. Pozostałe 17 grzywien z otrzymanej kwoty postanowił zatrzymać do dalszego swego rozdysponowania na czas powrotu $z$ pospolitego ruszenia, jednak na wypadek gdyby zginął na wojnie ,i tę kwotę resztę pieniędzy na ubogich rozkazał ${ }^{142}$.

Przeznaczenie grzywien na rzecz szpitali normowały polecenia - mandaty królewskie w miejscowościach, w których zostały wystawiane. Przykładowo w

${ }^{138}$ D. Adamska, P. Nocuń, „Czu troste und czu hulffe des zele”, Późnośredniowieczne ugody kompozycyjne z terenu Śląska, „Sobótka”, 59 (2004) s. 118-119, 124-128 (tabela 1); Wółkiewicz, Formy dobroczynności, s. 211-312.

${ }^{139}$ Zob. Dola, Opieka spoteczna i zdrowotna, s. 140.

${ }^{140}$ Góralski, Szpitale, s. 105, 107-109.

${ }^{141}$ Tamże, s. 106-107; J. Riabinin, Rada miejska lubelska w XVII w., Lublin 1931, s. 30.

${ }^{142}$ Surdacki, Edukacja i opieka, s. 284-286; M. Surdacki, Urzędów w XVII i XVIII wieku. Miasto-społeczeństwo-życie codzienne, Lublin 2007, s. 412-413. 
1564 r. Zygmunt August postanowił, że nikt nie może uprawiać rzemiosła w Lublinie, jeśli nie posiada prawa miejskiego, pod karą odebrania narzędzi i sprzedania ich na rzecz szpitala ${ }^{143}$.

Nieinstytucjonalne, poza szpitalne formy działalności charytatywnej, różnego typu zapomogi, a szczególnie środek pomocy najbardziej uniwersalny i zawsze spełniający swój cel - jałmużna, miały charakter doraźny, który mógł tylko czasowo zmniejszyć niedostatek. Jednak bardziej skuteczną opiekę dla różnych kategorii ubóstwa były w stanie zapewnić tylko szpitale, których liczba nigdy nie odpowiadała skali istniejących potrzeb.

Rozpowszechnioną formą dobroczynnych uczynków było umarzanie części wierzytelności. W ten sposób swe prywatne miłosierdzie okazywały dość często w XVII w., w stosunku do biednych wdów z licznym potomstwem, zamożniejsze warszawskie mieszczanki, które uwzględniając trudną sytuację rodzinną dłużniczek, darowywały im niespłacone zaległości, pożyczki czy inne zobowiązania ${ }^{144}$.

słowa kluczowe: jałmużna, bractwa, ubodzy, żebracy, legaty, testamenty

\section{BIBLIOGRAFIA}

\section{Źródła}

Constitutiones et decreta synodi dioecesanae Płocensis [...]Andrea Stanislao Kostka in Załuski Załuski [...] episcopo Plocensi Pultoviae 1733 [...] celebratae, Varsaviae, Typis Collegii Regii Societatis Jesu, Anno Domini 1735.

Constitutiones synodales dioecesis Varmiensis [...] 1610, Brunsbergae apud Georgium Schönfeles 1612.

Constitutiones synodales editae et promulgatae ab [...] A. S. K. Załuski [...] in dioecesana synodo celebrata [...]Anno Domini 1745, Brunsbergae Typis Collegii Societatis Jesu 1746.

Czartoryski T., Epistola pastoralis [...] Theodori Ducis in Klewan et Żukow Czartoryski episcopi Posnaniensis. Ad universum clerum et populum ejusdem dioecesis 1739, Varsaviae 1739 Typis S. R. M. Republicae Collegii Scholarum Pijarum.

Maciejowski B., Epistola pastoralis [...] 1601.

Poniatowski M.J, Ustanowienie Bractwa Miłosierdzia po parafiach w dyecezyi krakowskiey, Warszawa 1784.

Poniatowski M. J., Ustanowienie Bractwa Miłosierdzia po parafiach archi-diecezyi gnieźnieńskiey, Łowicz 1787.

Poniatowski M. J., Ustanowienie Bractwa Miłosierdzia po parafiach w dyecezyi płockiey, Warszawa 1777.

${ }^{143}$ J. Riabinin, Materiaty do historii miasta Lublina 1317-1792, Lublin 1938, s. 30.

${ }^{144}$ Karpiński, Kobieta, s. 283; tenże, Pauperes, s. 347-348. 
Reformationes Generales ad clerum et populum dioecesis Cracoviensis pertinentes ab [...] Martino Szyszkowski [...] episcopo Cracov. [...] in synodo diocesana [...] Anno 1621, Cracoviae in Officina Andreae Petricovij.

Statuta Synodalia Dioecesis Orthodoxae Kijoviensis publicata ab [...] Josepho Andrea Comite in Zaluskie Junosza Zaluski episcopo Kijoviense et Cernichoviense.1762, [...] Typographeo Culmae in Prussia 1766.

Synodus dioecesana ab [...] C. A Łubna Łubieński [...] celebrata Cracoviae [...] Anno Domini 1711 [...], Typis Francisci Czary.

Synodus dioecesana Leopoliensis sub [...]Venceslao Hieronymo de Boguslavice Sierakowski [...] Anno domini 1765 [...] celebrata, Leopoli Typis S. R. M. Academicis 1765

Synodus dioecesana Mednicensis, seu Samogitiae, sub auspicis [...] Antoni Dominici comitis in Łohoysk et Berdyczew Tyszkiewicz [...] Anno Domini 1752 [...] celebrata, Typis mandata Vilnae S. R. M. Academicis. Societatis Jesu.

Szaniawski K. F., Epistola pastoralis [...] Konstantini Felliciani Szaniawski Episcopi Cracoviensis [...] Anno Domini 1720, Cracoviae, Typis Francisci Cezary.

\section{Opracowania}

Adamska D., Nocuń P, „Czu troste und czu hulffe des zele”. Późnośredniowieczne ugody kompozycyjne z terenu Śląska, - „Śląski Kwartalnik Historyczny Sobótka”, 59 (2004) s. 111-139.

Antosiewicz K., Opieka nad chorymi i biednymi w krakowskim Szpitalu Świętego Ducha (1220-1741), „Roczniki Humanistyczne”, 26 (1978) z. 2, s. 35-79.

Antosiewicz K., Zakon Ducha Świętego w Polsce średniowiecznej, „Nasza Przeszłość”, 23 (1966) s. 167-198

Ataman J., Wacław Hieronim Sierakowski i jego rządy w diecezji przemyskiej, Warszawa 1936.

Augustyniak U., Testamenty ewangelików reformowanych w Wielkim Księstwie Litewskim, Warszawa 1992.

Bobowski K., Opieka społeczna, w: Legnica, red. S. Dąbrowski, Wrocław-Legnica 1998, s. 59-65.

Budzyński Z., Dzieje opieki społecznej w ziemi przemyskiej i sanockiej (XV-XVIII w.), Przemyśl-Kraków 1987.

Chodyński S., Bractwo, Encyklopedia Kościelna, t. 2, red. M. Nowodworski Warszawa 1873, s. 551-571.

Cynarski S, Ze studiów nad ludnością miasta Krosna w XVI-XVIII w., „Rocznik Przemyski”, 11 (1967) s. 75-93.

Czaja R., Rozwój szpitali miejskich w państwie Zakonu Krzyżackiego w Prusach, w: Szpitalnictwo w dawnej Polsce, red. M. Dąbrowska, J. Kruppé, Warszawa 1998, s. 135-144.

Dąbrowski K., Działalność społeczna cystersów w Oliwie w XII-XVI wieku, „Summarium”, 23 (1974) nr 3, s. 131-138

Dąbrowski K., Opactwo cystersów w Oliwie od XII do XVI wieku, Gdańsk 1975.

Derwich M., Benedyktyński klasztor Św. Krzyża na Łysej Górze w średniowieczu, Warszawa-Wrocław 1992.

Długokęcki W., W sprawie późnośredniowiecznych testamentów gdańskich, „Zapiski Historyczne", 76 (2011) z. 3, s. 115-139.

Dola K., Opieka społeczna i zdrowotna w Głogowie do czasów pruskich (1942), w: Misericordia et veritas. Księga pamiątkowa ku czci księdza biskupa Wincentego Urbana, red. J. Mandziuk, J. Pater, Wrocław 1986, s. 113-146. 
Dola K., Opieka społeczna Kościoła, w: Historia Kościoła w Polsce, red. B. Kumor, Z. Obertyński, t. 1, cz. 2, Poznań-Warszawa 1974, s. 120-122, 343-345, 368-373, 504506.

Dola K., Opieka społeczna w Księstwie Nyskim za czasów biskupa Franciszka Ludwika Neubugera (1683-1732), „Studia Teologiczno-Historyczne Śląska Opolskiego”, 9 (1981) s. 19-46.

Dola K., Szpitale średniowieczne Śląska. Rozwój historyczny, „Studia Teologiczno-Historyczne Śląska Opolskiego", 1 (1968) s. 239-292.

Fabiani B., Ludwika Maria i Francuzi w Warszawie 1646-1668, w: Warszawa XVI-XVII wieku, Warszawa 1977, s. 227-258.

Fankidejski J., Klasztory żeńskie diecezji chełmińskiej, Pelplin 1883.

Fankidejski J., Utracone kościoły i kaplice w dzisiejszej diecezji chełmińskiej podług urzędowych akt kościelnych, Pelplin 1880.

Flaga J., Działalność charytatywna bractw religijnych w XVII i XVIII wieku, w: Ecclesia et Status. Księga jubileuszowa z okazji 40-lecia pracy naukowej Profesora Józefa Krukowskiego, red. A. Dębiński, K. Orzeszyna, M. Sitarz, Lublin 2004, s. 377-399.

Geremek B., Ludzie marginesu społecznego w średniowiecznym Paryżu XIV-XV wiek, Wrocław 1971.

Geremek B., Świat opery żebraczej. Obraz włóczęgów i nędzarzy w literaturach europejskich XV-XVII wieku, Warszawa 1989.

Geremek B., Święty Antoni z Florencji o żebrakach i jałmużnie, w: Wieki średnie. Medium aevum. Prace ofiarowane Tadeuszowi Manteuffelowi w 60 rocznicę urodzin, red. A. Gieysztor, M.H Serejski, S. Trawkowski, Warszawa 1962, s. 239-237.

Geremek B., Żebracy w Italii późnego średniowiecza: Obraz literacki a środowisko społeczne, w: Społeczeństwo. Gospodarka. Kultura. Studia ofiarowane Marianowi Małowistowi w czterdziestolecie pracy naukowej, Warszawa 1974, s. 83-97.

Giedroyć F., Rys historyczny szpitala św. Łazarza w Warszawie, Warszawa 1897.

Głowacka A., Dobroczynność w obliczu śmierci w małych miastach wielkopolskich w drugiej połowie XVI i w XVII wieku, w: Choroba i śmierć w perspektywie społecznej w XIII-XXI wieku, red. D.K. Chojecki, E. Włodarczyk, Warszawa 2010, s. 95-111.

Głowacka-Penczyńska A., Kobieta w małych miastach Wielkopolski w drugiej połowie XVI i w XVII wieku, Warszawa 2010.

Głowacka-Penczyńska A., Testamenty mieszkańców małych miast wielkopolskich z XVII wieku, „Kwartalnik Historii Kultury Materialnej”, 59 (2011) nr 3-4, s. 381-393.

Główka D., Legaty pieniężne i rzeczowe na rzecz instytucji kościelnych w testamentach duchownych z diecezji płockiej w XVII wieku, „Kwartalnik Historii Kultury Materialnej", 59 (2011) nr 3-4, s. 409-413.

Góralski Z., Opieka społeczna i szpitalnictwo w dawnej Polsce (na przykładzie Lubelszczyzny), „Zeszyty Historyczne Uniwersytetu Warszawskiego”, 3 (1963) s. 82-101.

Góralski Z., Szpitale na Lubelszczyźnie w okresie przedrozbiorowym, cz. II, oprac. D. Wójcik-Góralska, Lublin 1999.

Grzybowski M., Kościelna działalność Michała Jerzego Poniatowskiego biskupa płockiego 1773-1785, w: Studia z historii Kościoła w Polsce, t. 7, Warszawa 1983, s. 4-225.

Guldon Z., Wizytacja parafii radomskich z 1747 roku, w: Radom i region radomski w dobie szlacheckiej Rzeczypospolitej, red. Z. Guldon, S. Zieliński, Radom 1996, s. 45-66.

Heck E., Struktura społeczna średniowiecznego Wrocławia na przełomie XIV/XV wieku, „Śląski Kwartalnik Historyczny Sobótka”, 7 (1952) s. 57-94. 
Jelonek-Litewka K, Arcybractwo Miłosierdzia i Banku Pobożnego w Krakowie, „Nasza Przeszłość", 61 (1984) s. 50-67.

Justyniarska-Chojak K., Legaty „,pobożne” dla bractw religijnych w Nowym Sączu (w pierwszej połowie XVII wieku, w: Bractwa religijne w średniowieczu i w okresie nowożytnym (do końca XVIII wieku), red. D. Burdzy, B. Wojciechowska, Kielce 2014, s. 235-245.

Karaskiewicz K., Teoria miłosierdzia według prymasa Michała Jerzego Poniatowskiego na podstawie jego listów, w: Charitas. Miłosierdzie i opieka społeczna w ideologii, normach postępowania i praktyce społeczności wyznaniowych w Rzeczypospolitej XV-XVIII wieku, red. U. Augustyniak, A. Karpiński, Warszawa 1999, s. 31-48.

Karpiński A., Dobroczynne i religijne legaty lwowskich mieszczan w świetle ich testamentów z lat 1550- 1700, „Kwartalnik Historii Kultury Materialnej”, 59 (2011) nr 3-4, s. 361-393.

Karpiński A., Kobieta w mieście polskim w drugiej połowie XVI i w XVII wieku, Warszawa 1996.

Karpiński A., Pauperes. O mieszkańcach Warszawy XVI i XVII wieku, Warszawa 1983.

Kasabuła T., „Proces do Dyecezyi i względem ubogich” biskupa wileńskiego Ignacego Massalskiego z dnia 17 XII 1786 roku, ,, Wiadomości Kościelne Archidiecezji Białostockiej", 9 (28), 2000, nr 1 (116), s. 193-196.

Kolankiewicz M., Schronienie. Historia Domu Małych Dzieci ks. G.P. Baudouina, Warszawa 1997.

Kopiczko A., Szpitalnictwo na Warmii w XVI - XVIII wieku, w: Szpitalnictwo w dawnej Polsce, s. 97-107.

Kossakowski J. K., Xiądz pleban, Warszawa 1786.

Kowalski W., Opieka społeczna i dobroczynność na terenie archidiakonatu sandomierskiego w dobie przedrozbiorowej, w: Charitas, Miłosierdzie i opieka społeczna w ideologii, normach postępowania i praktyce społeczności wyznaniowych w Rzeczypospolitej XV-XVIII wieku, red. U. Augustyniak, A. Karpiński, Warszawa 1999, s. 167-186.

Krętosz J., Organizacja archidiecezji lwowskiej obrządku łacińskiego od XV wieku do 1772 roku, Lublin 1986.

Kropidłowski Z., Dzieje miłosierdzia chrześcijańskiego w średniowiecznym Gdańsku, „Universitatis Gedanensis”, 3 (1991) nr 5, s. 36-47.

Księga pamiątkowa trzechsetlecia zgromadzenia księży misjonarzy (1625-1925), Kraków 1925.

Kujot S., Opactwo pelplińskie, Pelplin 1875.

Kuklo C., Kobieta samotna w społeczeństwie miejskim u schyłku Rzeczypospolitej szlacheckiej, Białystok 1998.

Kumor B., Kościelne stowarzyszenia świeckich na ziemiach polskich w okresie przedrozbiorowym, „Prawo Kanoniczne”, 10 (1967) nr 1-2, s. 289-356.

Kumor B., Statuty Bractwa Literackiego Nauki Chrześcijańskiej przy kolegiacie św. Małgorzaty w Nowym Sączu, „Archiwa Biblioteki Muzea i Kościelne”, 2 (1961) s. 351389.

Kurczewski J., Biskupstwo wileńskie, Wilno 1912.

Lapis D., Lapis B., Beginki w Polsce w XVIII-XV wieku, „Kwartalnik Historyczny”, 79 (1972) nr 3, s. 522-544.

Lesiak E., Kobiety z rodu Radziwiłłów w świetle inwentarzy i testamentów (XVI-XVIII W.), w: Administracja i życie codzienne w dobrach Radziwiłłów XVI-XVIII wieku, red. U. Augustyniak, Warszawa 2009, s. 113-194. 
Łoziński W., Patrycjat i mieszczaństwo lwowskie w XVI i XVII wieku, Lwów 1902.

Łukaszewicz J., Krótki opis historyczny kościołów parochialnych, kościołów, kaplic, klasztorów, szkółek parochialnych, szpitali i innych zakładów dobroczynnych dawnej diecezji poznańskiej, t. 1, Poznań 1858.

Mandziuk J., Historia Kościoła Katolickiego na Śląsku. Średniowiecze, t. 1, cz. 2, Warszawa 2004.

Mandziuk J., Opieka społeczna Kościoła katolickiego na Śląsku do czasów pruskich (1742), „Resovia Sacra”, 8 (2001) s. 129-166.

Markwitzówna A., Bractwo Miłosierdzia w Poznaniu w XVIII w., „Kronika Miasta Poznania", 2 (1948) nr 2, s. 20-127.

Maroszek J., Wileńskie przytułki - szpitale w XVI-XVIII wieku, w: Cała historia to dzieje ludzi... studia z historii społecznej ofiarowane prof. Andrzejowi Wyczańskiemu w 80. rocznice urodzin i 55-lecie pracy naukowej, red. C. Kukla, Białystok 2004, s. 191218.

Wincentego a Paulo w Polsce (1651-2001). I. Dzieje, red. S. Rospond, Kraków 2001.

Możejko B., Rozrachunek z życiem doczesnym. Gdańskie testamenty mieszczańskie z XV i początku XVI wieku, Gdańsk 2010.

Mrozowski K., Religijność mieszczan późnośredniowiecznej Warszawy w świetle najstarszych zachowanych testamentów, „Kwartalnik Historii Kultury Materialnej”, 58 (2010) nr 2, s. 191-196.

Oliński P., Mieszczanin w trosce o zbawienie. Uwagi o memoratywnych funkcjach fundacji mieszczańskich w wielkich miastach pruskich, w: Ecclesia e civitas. Kościół i życie religijne w mieście średniowiecznym, red. H. Manikowska, H. Zaremska, Warszawa 2002, s. 347-359.

Partyka W., Opieka społeczna w Ordynacji Zamojskiej w XVII-XVIII wieku, Lublin 2008.

Pawlikowska W., Testamenty duchowieństwa diecezji wileńskiej w drugiej połowie XVI w. Prawo i praktyka, „Kwartalnik Historii Kultury Materialnej”, 59 (2011) nr 3-4, s. 395-407.

Pękacka-Falkowska K., Dyscyplinować i pomagać - toruńskie akuszerki miejskie w XVIII w. (kilka uwag na marginesie przysiąg i porządków akuszerek), „Medycyna Nowożytna", 19 (2012) z. 2, s. 65-105.

Pękacka-Falkowska K., Wielka epidemia chorób zakaźnych w nowożytnym Toruniu. Wielka zaraza w trakcie III wojny północnej jako fakt totalny, Toruń 2012 (rps, praca doktorska, Biblioteka Uniwersytetu Mikołaja Kopernika w Toruniu).

Przyboś A., Rzeszów na przełomie XVI i XVII wieku, w: Pięć wieków miasta Rzeszowa, red. F. Błoński, Warszawa 1958, s. 63-159.

Riabinin J., Rada miejska lubelska w XVII w., Lublin 1931.

Rochici, Podręczna Encyklopedia Kościelna, red. Z. Chełmicki, t. 33-34, Warszawa 1914, s. 288.

Rodziński A., Bogactwo i ubóstwo w świetle myśli chrześcijańskiej pierwszych trzech stuleci, ,Vox Patrum”, 16 (1996) z. 30-31, s. 85-90.

Salwa T., Litewska prowincja księży misjonarzy (1794-1842), „Nasza Przeszłość”, 56 (1981) s. 147-235.

Schletz A., Zarys historyczny zgromadzenia sióstr miłosierdzia w Polsce, „Nasza Przeszłość", 12 (1960) s. 59-172.

Sieciechowiczowa L., Życie codzienne w renesansowym Poznaniu 1518-1619, Warszawa 1976.

Staniszewski P., Szpitalnictwo kościelne w archidiakonacie łęczyckim i łowickim do 1795 roku, Warszawa 2004. 
Starnawska M., Między Jerozolimą a Łukowcem. Zakony krzyżowe na ziemiach polskich w średniowieczu, Warszawa 1999.

Stopka K., Szkoły katedralne metropolii gnieźnieńskiej w średniowieczu, Kraków 1994.

Subera I., Synody prowincjonalne arcybiskupów gnieźnieńskich, Warszawa 1981.

Surdacki M., Edukacja i opieka społeczna w Urzędowie XV-XVIII wiek, Lublin 2004.

Surdacki M., Opieka społeczna w Wielkopolsce Zachodniej w XVII-XVIII wieku, Lublin 1992.

Surdacki M., Urzędów w XVII i XVIII wieku. Miasto. Społeczeństwo. Życie codzienne, Lublin 2007.

Szarszewbłogosławieniski A., Dokumenty fundacji nieszpitalnych jako źródło do badań na d strukturą wewnętrzną szpitali gdańskich w XVII i XVIII wieku, „Rocznik Gdański”, 56 (2006) s. 163-177.

Świątecka M., Św. Wincenty a Polska, „Nasza Przeszłość”, 11 (1960) s. 35-100.

Testamenty szlachty krakowskiej XVII - XVIII w. opr. A. Faleniowska-Gradowska, Kraków 1997.

Tyszewicz-Obara A., Życie codzienne średniowiecznej łaźni, w: Rycerze Wędrowcy Kacerze. Studia z historii średniowiecznej i wczesnonowożytnej Europy Środkowej, red. B. Wojciechowska, W. Kowalski, Kielce 2013, s. 357-364.

Wachholz L., Szpitale krakowskie 1220-1920, t. 2, Kraków 1924.

\section{TYPES AND FORMS OF HANDOUTS IN PRE-PARTITION POLAND}

\section{Summary}

The problem of the sick, poor, old, orphans and those who are in need continuously appeared throughout human civilization. The Church played a huge, even dominant role in providing assistance to these people, as its doctrine of mercy inspired his followers to support the needy. This aid was rendered primarily through hospitals - which until the Enlightenment functioned as poorhouses; to a lesser extent by brotherhoods of charity. However, the most common form of assistance was a handout called ,daily mercy”; according to the medieval concept of mercy, a ,gold" and universal remedy for all human misery, because available for all the people from different classes and social groups. Giving handouts was something natural and done every day, something inherent in the mentality of medieval and modern society. It was an important part of all church and family ceremonies, public meetings, gatherings, and travel.

There were different forms of giving handouts. One of them was a handout from individuals, which was usually practiced in the form of so-called testamentary handouts bequeathed in wills. Bequests and dispositions concerning handouts were made both to individuals (beggars and the poor) and a group of people living on the streets or in their homes. Also, the authors of their wills often bequeathed part of their wealth to charitable institutions, primarily hospitals and residents living in them.

Informal handouts were rendered even more often; they were given by individuals in a spontaneous manner either to people who were in hospitals, or beggars who were not connected with any charitable institutions. 
Another form of supporting the needy was a funeral handout, distributed by the family of the deceased to beggars participating in the funeral. Sometimes it resulted from the will of the deceased, who before his death obligated relatives (in his will or by his words) to bestow handouts on the poor present in the burial ceremony. Beggars also received support participating at the funeral reception.

The above-mentioned types of handouts can be defined as non-institutional ones. Sometimes, however, handouts were given by various institutions and organizations such as parishes, monasteries, hospitals and charitable brotherhoods, which were appointed for this very purpose, e.g. brotherhoods of the poor, hospitaller brotherhoods or brotherhoods of charity.

Institutional forms of assistance include the ones provided by bishops, monarchs or municipal offices. Finally, there were also handouts coming from criminal penalties, because an accused or convicted person was obliged to help the needy as a substitute for any other type of sanction, for example flogging or prison. Sometimes the courts did not charge administrative fees, allocating them to beggars.

Keywords: handout, brotherhoods, the poor, beggars, legacy,will 